\title{
New Era of Diacylglycerol Kinase, Phosphatidic Acid and Phosphatidic Acid-Binding Protein
}

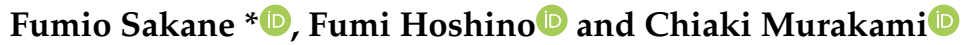 \\ Department of Chemistry, Graduate School of Science, Chiba University, Chiba 263-8522, Japan; \\ f.hoshino@chiba-u.jp (F.H.); 12s3039@chiba-u.jp (C.M.) \\ * Correspondence: sakane@faculty.chiba-u.jp; Tel.: +81-43-290-3695
}

Received: 26 August 2020; Accepted: 14 September 2020; Published: 16 September 2020

check for updates

\begin{abstract}
Diacylglycerol kinase (DGK) phosphorylates diacylglycerol (DG) to generate phosphatidic acid (PA). Mammalian DGK consists of ten isozymes $(\alpha-\kappa)$ and governs a wide range of physiological and pathological events, including immune responses, neuronal networking, bipolar disorder, obsessive-compulsive disorder, fragile $X$ syndrome, cancer, and type 2 diabetes. DG and PA comprise diverse molecular species that have different acyl chains at the $s n-1$ and $s n-2$ positions. Because the DGK activity is essential for phosphatidylinositol turnover, which exclusively produces 1-stearoyl-2-arachidonoyl-DG, it has been generally thought that all DGK isozymes utilize the DG species derived from the turnover. However, it was recently revealed that DGK isozymes, except for DGKE, phosphorylate diverse DG species, which are not derived from phosphatidylinositol turnover. In addition, various PA-binding proteins (PABPs), which have different selectivities for PA species, were recently found. These results suggest that DGK-PA-PABP axes can potentially construct a large and complex signaling network and play physiologically and pathologically important roles in addition to DGK-dependent attenuation of DG-DG-binding protein axes. For example, 1-stearoyl-2-docosahexaenoyl-PA produced by DGK $\delta$ interacts with and activates Praja-1, the E3 ubiquitin ligase acting on the serotonin transporter, which is a target of drugs for obsessive-compulsive and major depressive disorders, in the brain. This article reviews recent research progress on PA species produced by DGK isozymes, the selective binding of PABPs to PA species and a phosphatidylinositol turnover-independent DG supply pathway.
\end{abstract}

Keywords: diacylglycerol kinase; phosphatidic acid; phosphatidic acid-binding protein; fatty acid; docosahexaenoic acid; phosphatidylinositol turnover; lipid sensor

\section{Introduction}

Diacylglycerol kinase (DGK) phosphorylates diacylglycerol (DG) to produce phosphatidic acid (PA) (Figure 1) [1-5]. Both DG and PA are well-established second messengers. Therefore, because DGK can potentially serve as a DG consumer as well as a PA generator (Figure 1), DGK regulates the balance between DG and PA. DG plays important roles in regulating several signal transduction proteins [6-9], such as conventional protein kinase C (cPKC), novel PKC (nPKC), protein kinase D (PKD, atypical PKC (aPKC)), Ras guanyl nucleotide-releasing protein (GRP), Unc-13 (Uncoordinated-13), chimaerin (Rac-specific GTPase-activating protein (GAP)) and transient receptor potential channel (TRPC, $\mathrm{Ca}^{2+}$-permeable cation channel) 2, all of which, except for TRPC2, contain one or two DG-binding C1 domain(s) (Figure 1) $[6,9,10]$. 


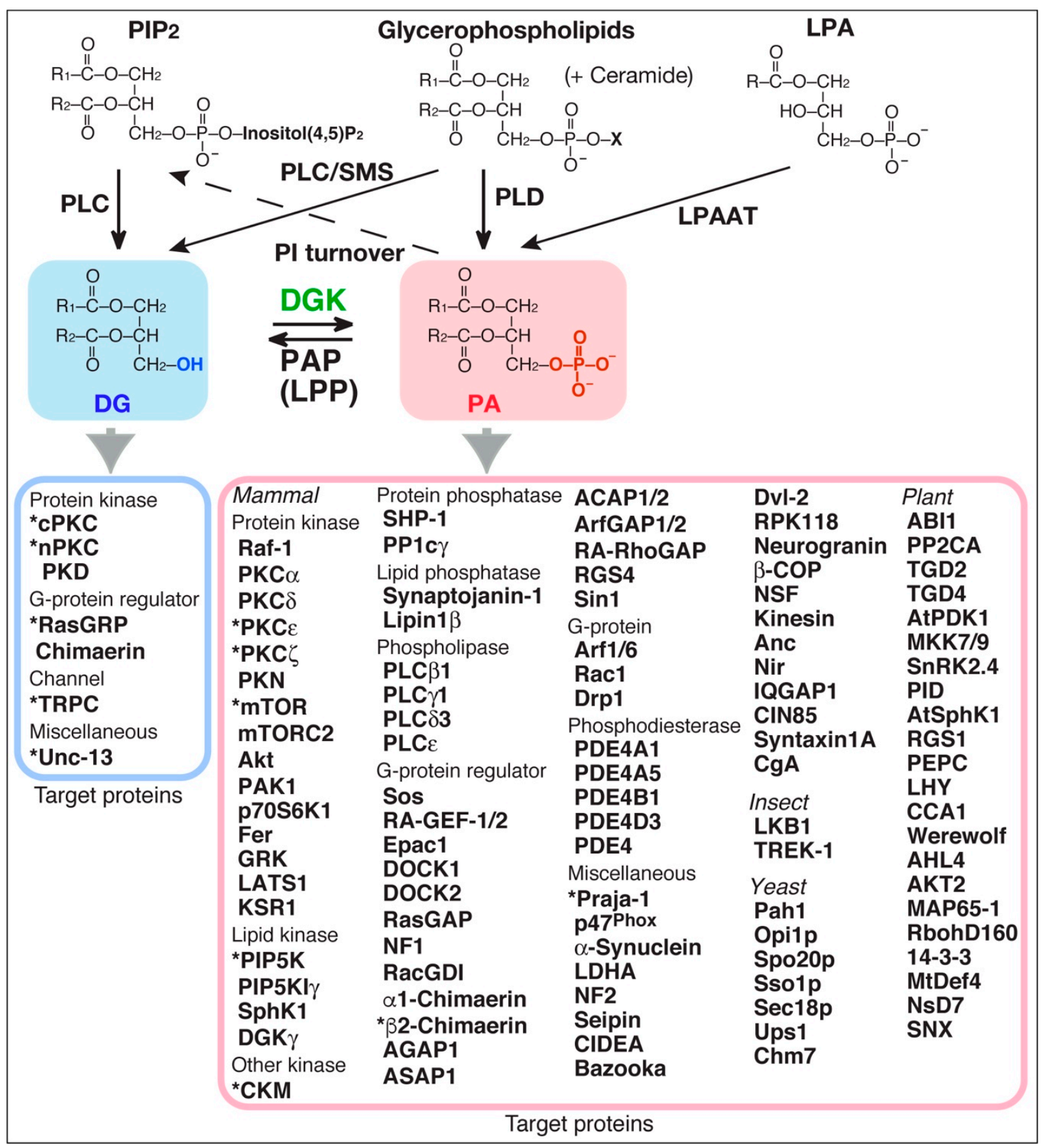

Figure 1. Target proteins of substrate (DG) and reaction product (PA) of DGK. Asterisks indicate target proteins that have been strongly suggested to be regulated by DGK isoforms through consumption of DG or production of PA. PAP, PA phosphatase; LPP, lipid phosphate phosphatase; PC, phosphatidylcholine; PI, phosphatidylinositol; $\mathrm{PIP}_{2}$, PI 4,5-bisphosphate; PLC, phospholipase C; PLD, phospholipase D; cPKC, conventional protein kinase C (PKC $\alpha, \beta$ and $\gamma$ ); nPKC, novel PKC (PKC $\delta, \varepsilon, \eta$ and $\theta$ ); PKD, protein kinase D; Unc-13, uncoordinated-13; RasGRP, Ras guanyl nucleotide-releasing protein; TRPC, transient receptor potential channel; chimaerin (RacGAP); Raf-1/C-Raf, rapidly accelerated fibrosarcoma (serine/threonine protein kinase); PKC $\zeta$ (atypical PKC (aPKC)); PKN (aPKC); mTOR, mammalian target of rapamycin (serine/threonine protein kinase); mTORC2, mTOR complex 2; Akt/protein kinase B; PAK1, p21-activated kinase 1; p70S6K1/S6K1, ribosomal protein S6 kinase $\beta$-1; Fer (tyrosine protein kinase); GRK, G protein-coupled receptor kinase; LATS1, large tumor suppressor kinase 1; KSR1, kinase suppressor of Ras 1 (serine/threonine protein kinase/scaffold protein); PIP5K, PI-4-phosphate 5-kinase; SphK1, sphingosine kinase 1; CKM, creatine kinase-muscle type; SHP-1, Src homology 2 
domain-containing protein-tyrosine phosphatase 1; PP1c, protein phosphatase-1 catalytic subunit; synaptopjanin-1 (PI(4,5) $\mathrm{P}_{2}$-5-phosphatase); lipin1 $\beta$ (PAP); Sos, son of sevenless (Ras guanyl nucleotide exchange factor (GEF)); RA-GEF-1/2/PDZ-GEF (Rap1GEF); Epac1 (RapGEF); DOCK, dedicator of cytokinesis (RacGEF); RasGAP, Ras GTPase-activating protein; NF1, neurofibromatosis type-1 (RasGAP); RacGDI, Rac guanosine dissociation inhibitor; AGAP (ADP-ribosylation factor (Arf) 1 GAP); ASAP1 (Arf1GAP); ACAP1/2 (Arf6GAP1/2); RA-RhoGAP, Rap-activated RhoGAP; RGS, regulator of G-protein signaling protein; Sin1, SAPK-interacting protein 1 (suppressor of Ras signaling); Arf, ADP-ribosylation factor; Rac1, Ras-related C3 botulinum toxin substrate 1 (Rho family, small GTP binding protein); Drp1, dynamin-related protein 1 (dynamin superfamily GTPase); PDE, cAMP phosphodiesterase; Praja-1 (E3 ubiquitin ligase acting on serotonin transporter); $47^{\text {phox }}$ (component of NADPH oxidase); $\alpha$-synuclein (associated with Parkinson's disease); NF2 (Hippo upstream component); seipin (role in lipid droplet formation); CIDEA, cell-death-induced DFF45-like effector A (lipid droplet protein); Bazooka/Par-3 (cell polarity regulator); Dvl-2, dishevelled homolog (mediator of the Wnt signaling pathway); RPK118 (SphK1-binding protein); Neurogranin (calmodulin-binding protein); $\beta$-COP (coatmer protein); NSF, N-ethylmaleimide-sensitive factor (ATPase associated with diverse cellular activity (AAA)); Kinesin (motor protein); Anc, adenine nucleotide carrier protein; Nir (PI-transfer protein); IQGAP1, IQ motif-containing guanosine triphosphatase-activating protein 1 (scaffold protein); CIN85, Cbl-interacting protein of $85 \mathrm{kDa}$ (adaptor/scaffold protein); syntaxin1A (soluble NSF attachment protein receptor (SNARE) protein); CgA, chromogranin A (a representative constituent of the core aggregate within secretory granules); LKB1, liver kinase B1 (serine/threonine protein kinase); TREK-1, TWIK-related $\mathrm{K}^{+}$channel type 1 (potassium channel); Pah1 (PAP); Opi1p (transcriptional repressor); Spo20p (SNARE protein); Sso1p (SNARE protein); Sec18p/NSF (AAA); Ups1 (mitochondrial fusion protein in the inner membrane); Chm7 (part of an ESCRT-III-like complex); ABI1, ABA-insensitive 1 (protein phosphatase); PP2CA, protein phosphatase 2CA; TGD, trigalactosyldiacylglycerol (chloroplast lipid transport protein); AtPDK1 (Arabidopsis thaliana 3-phosphoinositide-dependent protein kinase-1); MKK7/9 (mitogen-activated protein kinase kinase 7/9); SnRK2.4, sucrose nonfermenting-1-related protein kinase 2.4; PID, protein kinase PINOID (regulator of auxin signaling); AtSphK1, Arabidopsis thaliana sphingosine kinase 1; PEPC, phosphoenolpyruvate carboxylase; LHY (late elongated hypocotyl, transcription factor involved in the circadian clock); CCA1 (circadian clock associated 1, transcription factor involved in the circadian clock); Werewolf (MYB transcription factor); AHL4, AT-hook motif nuclear localized protein 4 (transcription factor to regulate triacylglycerol degradation for seeding establishment); AKT2, potassium channel; MAP65-1, microtubule-associated protein 65-1; RbohD160, respiratory burst oxidase homolog D 160; 14-3-3 protein (member of a family of regulatory molecules); MtDef4, Medicago truncatula defensin 4; NsD7, Nicotiana suaveolens defensin 7; SNX, sorting nexin (suppressing vascular degradation).

In addition to DG, PA has been reported to control a number of signaling proteins in mammals [11-17] such as protein kinases, including Raf-1 (C-Raf) kinase [18-20], PKC $\varepsilon$ (nPKC) [21,22],

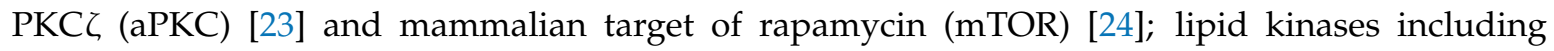
phosphatidylinositol (PI)-4-phosphate 5-kinase (PIP5K) [25,26] and sphingosine kinase (SphK) 1 [27]; protein phosphatases including protein phosphatase-1 catalytic subunit (PP1c) [28]; lipid phosphatases including Lipin $1 \beta$ [29]; phospholipases including phospholipase C (PLC) $\beta 1$ and $\gamma 1$ [30]; G-protein regulators including RasGAP [31] and chimaerin [32,33]; G-proteins including ADP-ribosylation factor (Arf) 1 [34] and Rac1 [35,36]; phosphodiesterases including cAMP phosphodiesterase (PDE)-4A1 [37,38] and 4B1 [39]; and miscellaneous proteins including Praja-1 [40], p47 ${ }^{\text {phox }}$ [41] and $\alpha$-synuclein [42,43] (Figure 1). Other than in mammals, many regulatory proteins in insects, yeasts, and plants also associate with PA. It is noteworthy that the number of PA-binding proteins (PABPs) is far greater than that of DG-binding proteins (DGBPs). The greater number may reflect that there are no common binding motifs like the $\mathrm{C} 1$ domain for DG binding. 
To date, 10 mammalian DGK isozymes (DGK $\alpha, \beta, \gamma, \delta, \varepsilon, \zeta, \eta, \theta, \iota$ and $\kappa)$ have been identified (Figure 2) [1-5]. These DGK isozymes commonly contain a catalytic domain and at least two C1 domains (cysteine-rich domains) and are divided into five groups (type I-V) according to their structural features (Figure 2) [1-5]. DGK $\beta, \gamma, \delta, \eta, \zeta$, and $\iota$ have one to three alternative splice variants, which add further diversity and complexity to DGK (Figure 2). DGK isozymes have been reported to be involved in many physiological events, including cell proliferation and migration, glucose intake, immunity and neuronal network construction, and pathogenesis of a wide variety of diseases, exemplified by cancer, epilepsy, obsessive-compulsive disorder (OCD), bipolar disorder (BPD), fragile X syndrome (FXS), immunodeficiency, cardiac hypertrophy, hypertension, and type 2 diabetes (T2D) [1-5,44-48].

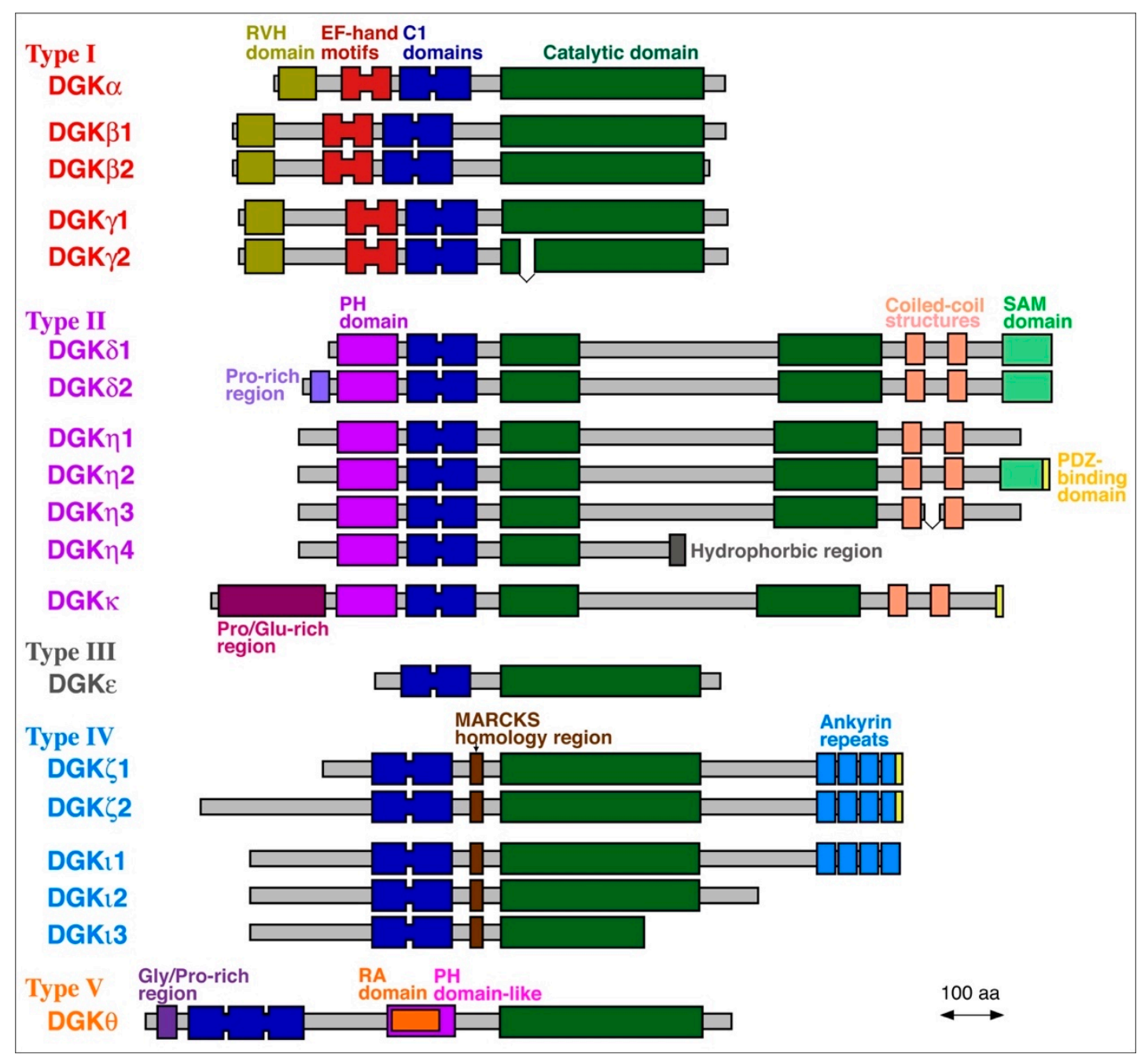

Figure 2. Mammalian DGK family proteins. Alternative splice variants are also shown. MARCKS, myristoylated alanine-rich C-kinase substrate; PDZ, postsynaptic density 95, discs large, zonula occludens-1; PH: pleckstrin homology; RA, Ras-associated; RVH, recoverin homology; SAM, sterile $\alpha$-motif. 
There are several target proteins that have been strongly suggested to be regulated by DGK isoforms through consumption of DG or production of PA. For DG consumption, it was reported that DGK $\alpha$ [49,50], DGK $\beta$ [51] and DGK $\gamma$ [52] inhibited RasGRP1, PKC $\beta I$, and PKC $\gamma$, respectively, through consumption of DG (Figure 1). Moreover, type I DGKs $(\alpha, \beta$ and $\gamma)$ inhibit TRPC 2 via DG reduction [53]. DGK $\delta$ interacts with PKC $\alpha, \mathrm{PKC} \delta, \mathrm{PKC} \varepsilon$, and PKC $\eta$ and attenuates their DG-dependent activities [54-56]. DGK $\zeta$ reduces the activities of PKC $\alpha$ [57,58] and RasGRP1 [59]. DGKı inhibits RasGRP3, which activate Rap1 [60]. R59022 (a broad DGK inhibitor)-sensitive DGK isozyme(s) regulates subcellular localization of PKC $\varepsilon$ via an increase in DG levels [22].

With respect to PA production by DGK, DGK $\zeta$ was demonstrated to enhance the activities of mTOR [61] and PIP5KI $\alpha$ [62] through increases in PA levels (Figure 1). It was reported that DGK $\alpha$ and DGK $\gamma$ activated PKC $\zeta[63,64]$ and $\beta 2$-chimaerin [65], respectively, probably via PA production. DGK $\delta$ was recently revealed to activate Praja-1, the E3 ubiquitin ligase acting on the serotonin transporter in the brain, through PA production $[40,66]$. It was demonstrated that creatine kinase-muscle type (CKM) functionally associated with DGK $\delta$ and was activated by PA $[67,68]$.

DG and PA consist of a variety of molecular species that have different acyl chains, which have diverse numbers of carbon atoms (14-22) and double bonds (0-6), at the sn-1 and sn-2 positions; consequently, mammalian cells contain at least 50 structurally distinct DG and PA species. DGK activity is one of the components of the PI turnover. Therefore, it has generally been thought, dogmatically, that DG utilized by DGK is solely derived from phosphatidylinositol (PI) turnover, which exclusively produces 1-stearoyl-2-arachidonoyl-DG (18:0/20:4-DG) (X:Y = the total number of carbon atoms: the total number of double bonds in the fatty acyl moiety of the glycerol backbone) (Figure 1). Only DGK $\varepsilon$ exhibits selectivity to 18:0/20:4-DG in vitro [69,70] and in vivo [71]. However, other isozymes do not have such selectivity in vitro [72-76]. Studies in the recent decade provided data strongly suggesting that DGK isozymes, except for DGKe, utilize a variety of DG species but not PI turnover-derived 18:0/20:4-DG (Figure 3).

As described above, a number of PABPs in mammals have been identified to date (Figure 1) [11-17]. However, only a few PA species-selective ones have been found. Moreover, the PA species-selectivity of only a small part of PABPs has been determined. Therefore, we attempted to identify PA species-selective binding proteins using 16:0/16:0-PA and 18:0/22:6-PA and, consequently, found several PABPs that interact with different PA species.

In this review, we shed light on PAs, especially the diversity of PA molecular species, produced by DGK isozymes and on PABPs, especially those that possess selectivity for PA molecular species. We will also touch on a PI turnover-independent upstream pathway of DGK that was recently found. Moreover, a new PA probe, which is reliable and widely applicable, will be briefly mentioned. 


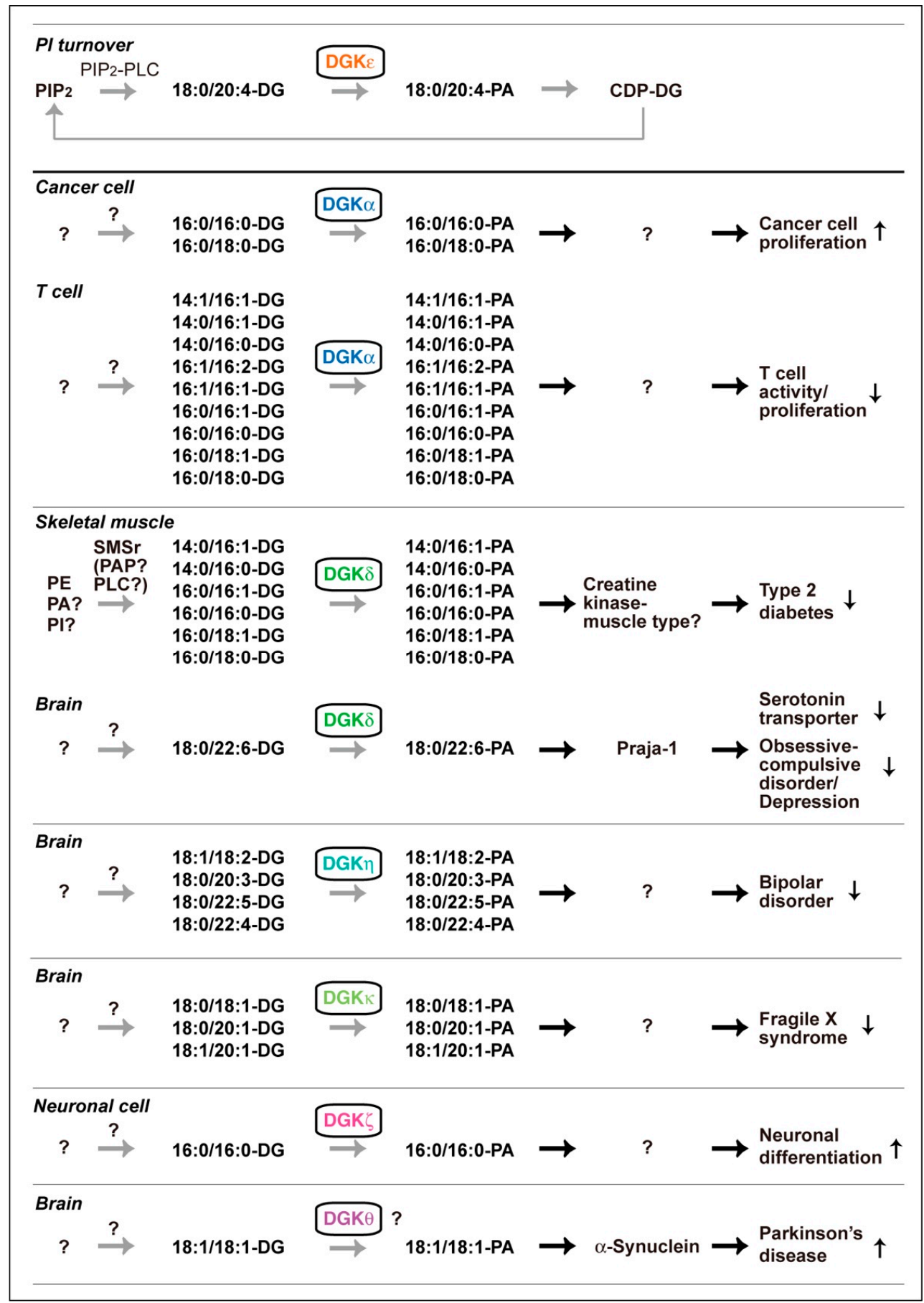

Figure 3. Various DGK isozyme-dependent DG species phosphorylation pathways that are independent of PI turnover. $\mathrm{PIP}_{2}$, phosphatidylinositol 4,5-bisphosphate; CDP-DG, cytidine diphosphate diacylglycerol; SMSr, sphingomyelin synthase-related proteins; PAP, PA phosphatase. PA molecular species produced by DGK $\beta$, DGK $\gamma$ and DGKı have not been determined.

\section{PA Molecular Species Produced by DGK Isozymes Except for DGKe}

DGK $\varepsilon$ (type III) was purified and it clearly showed selectivity for 18:0/20:4-DG in vitro (Figure 3) [70]. Moreover, cDNA-cloned DGKe selectively phosphorylated 18:0/20:4-DG in vitro [69]. Rodriguez de Turco et al. reported that knockout (KO) of DGKe indeed disturbed PI turnover [71]. Interestingly, DGK $\varepsilon$ is strongly expressed in Purkinje cells of the cerebellum and pyramidal cells of the hippocampus and regulates seizure susceptibility and long-term potentiation [71], which are 
governed by PI turnover. Taken together, these results indicate that DGK $\varepsilon$ is an essential component of PI turnover and exerts its physiological functions as a component of PI turnover in the brain (Figure 3).

On the other hand, nine other isozymes, except for DGK $\varepsilon$, fail to show selectivity for 18:0/20:4-DG in vitro [72-76]. Therefore, we questioned whether these nine isozymes indeed utilize PI turnover-derived 18:0/20:4-DG species in cells and organs. However, it has been difficult to quantitatively determine small changes in PA species levels caused by $\mathrm{KO}$ and silencing of a DGK isozyme in physiological and pathological events. Liquid chromatography-mass spectrometry (LC-MS) is a powerful tool to detect different molecular species of phospholipids in cells. However, PA was difficult to detect with high accuracy and reproducibility in the general LC conditions because of ion suppression by other major phospholipids, phosphatidylcholine (PC) and sphingomyelin [77]. Therefore, we optimized mobile phases using silica column LC to separate PA from major phospholipids and confirmed that PA species were quantitatively and reproducibly detected in LC-MS [77]. Then, we determined the PA molecular species produced by DGK isozymes in cells and organs and found that a variety of PA species other than 18:0/20:4-PA were generated by DGK isozymes. Intriguingly, these results do not support the dogma that all DGK isozymes utilize DG derived from PI turnover and instead support a new view that DGK isozymes, except for DGK $\varepsilon$, utilize DG species derived from pathways independent of PI turnover, as described below (Figure 3).

\section{1. $D G K \alpha$}

DGK $\alpha$, which is a type I isozyme, was first identified by cDNA cloning $[78,79]$. This isozyme possesses a recoverin homology $(\mathrm{RVH})$ domain and tandem repeats of two $\mathrm{Ca}^{2+}$-binding EF-hand motifs $[80,81]$ (Figure 2). Several lines of evidence suggested that the $\mathrm{Ca}^{2+}$-induced dissociation of the intramolecular interaction between the EF-hand motifs and the C1 domains of DGK $\alpha$ is the key event that regulates the activity of the enzyme [82-84].

DGK $\alpha$ has been repeatedly reported to be a promising target for anticancer drugs [47,85]. DGK $\alpha$, which is abundantly expressed in several cancer cells, such as melanoma $[63,86]$, hepatocellular carcinoma [87], and lymphoma [88], enhances cell proliferation and inhibits apoptosis. Moreover, it has been noted that DGK $\alpha$ activates angiogenesis signaling [89] and that this isozyme plays a key role in cancer cell migration [90]. Recently, LC-MS revealed that the production of palmitic acid (16:0)-containing PA species such as 16:0/16:0- and 16:0/18:0-PA were attenuated by CU-3, a DGK $\alpha$-selective inhibitor [91], in AKI melanoma cells under starved conditions (Figure 3) [92]. Therefore, these findings support the insight that inhibitory analogs (antagonists) of 16:0/16:0- and 16:0/18:0-PA can be therapeutics against tumor cell growth.

In addition to being expressed in cancer cells, DGK $\alpha$ is highly expressed in T cells [78]. In contrast to cancer cells, DGK $\alpha$ facilitates the immune nonresponsive (nonproliferation) state known as $\mathrm{T}$ cell clonal anergy $[49,93,94]$. T cell anergy induction represents the main mechanism by which advanced tumors avoid immune action [95]. Indeed, DGK $\alpha$ limits the antitumor immune response by tumor-infiltrating $\mathrm{CD}^{+} \mathrm{T}$ cells [96]. Therefore, the inhibition of DGK $\alpha$ activity is thought to enhance T cell activity, which governs cancer immunity $[44,85,97,98]$. We recently found that palmitic acid (16:0)- and/or palmitoleic acid (16:1)-containing phosphatidic acids such as 14:1/16:1-, 14:0/16:1-, 14:0/16:0-, 16:1/16:2-, 16:1/16:1-, 16:0/16:1-, 16:0/16:0-, 16:0/18:1- and 16:0/18:0-PA are generated by DGK $\alpha$ in starved Jurkat $\mathrm{T}$ cells (Figure 3) [99]. Intriguingly, the profile in starved T cells (palmitic acid- and/or palmitoleic acid (16:1)-containing PA species) [99] is different from that in starved melanoma cells (palmitic acid-containing PA species) [92]. Therefore, DGK $\alpha$ generates distinct PA species in different cells, and the differences in the PA molecular species may account for the opposing functions of DGK $\alpha$ in cancer and T cells.

DGK $\alpha$-selective inhibitors would be dual effective compounds (i.e., ideal cancer therapy candidates) because, as described above, they attenuate cancer cell proliferation and simultaneously enhance immune responses, including anticancer immunity [100]. Indeed, a DGK $\alpha$-selective inhibitor, CU-3, induced both cancer cell apoptosis and T-cell activation [91,92]. Other DGK $\alpha$-selective 
inhibitors, ritanserin [101] and analogs of Amb639752 (11 and 20) [102], were recently reported as well. These compounds are expected to be able to become ideal cancer drugs.

\section{2. $D G K \zeta$}

DGK乙 (type IV) contains a MARCKS (myristoylated alanine-rich C kinase substrate) phosphorylation site domain and four ankyrin repeats (Figure 2) [72,103]. Topham et al. [104] demonstrated that the nuclear-localization signal of DGK $\zeta$ is located in a MARCKS phosphorylation site domain and that PKCs $\alpha$ and $\gamma$ regulate the mode of DGK $\zeta$ localization by phosphorylation of the domain. DGK $\zeta$-mediated synaptic conversion of DG to PA is required for the maintenance of dendritic spines [105]. Moreover, DGK $\zeta$, syntrophin, and Rac1 form a ternary signaling complex that controls neurite outgrowth in N1E-115 neuroblastoma cells [106].

Previous reports showed that the level of PA was increased during neuronal differentiation $[107,108]$. However, it has not been revealed what PA molecular species are produced. Recently, 16:0/16:0-PA and, to a lesser extent, 14:0/16:0-PA and 16:0/18:0-PA, were found to be exclusively generated during

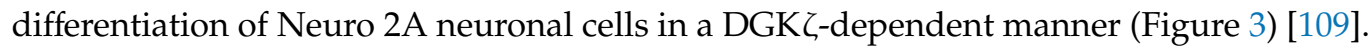

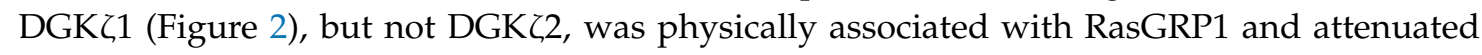
RasGRP1 activity by DG consumption [59]. Therefore, in addition to DGK $\alpha, \mathrm{DGK} \zeta$ acts as a suppressor of $\mathrm{T}$ cell functions and its inhibitors are expected to be useful for cancer immunotherapy $[44,85,98,110]$. DGKs $\zeta$ and $\alpha$ appear to share the same function (inhibition of RasGRP1 activity in T cells and consequently attenuation of T cell activity). Indeed, the combination of the inhibition of DGK $\alpha$ and DGK $\zeta$ additively or synergistically induces activation of T cells [111]. However, it is still unclear what PA species are generated by DGK $\zeta$ in T cells.

\section{3. $D G K \delta$}

DGK $\delta[112,113]$ has a pleckstrin homology (PH) domain at its $\mathrm{N}$-terminus and a sterile $\alpha$ motif (SAM) domain at its C-terminus (Figure 2). Alternative splice variants, $\delta 1$ and $\delta 2$, have different N-terminal regions (Figure 2) $[112,113]$. cPKC phosphorylates the PH domain of DGK $\delta$ and regulates its subcellular localization [114]. The isozyme forms homo-oligomers via its SAM domain [115-117].

DGK $\delta$ is strongly expressed in the skeletal muscle [112]. DGK $\delta$ regulates glucose transport $[54,56,118]$ and contributes to exacerbating the severity of type 2 diabetes (T2D) [54,56]. It was recently found that, in response to high glucose-stimulation, 16:0- and/or 16:1-containing PA species such as 14:0/16:1-PA, 14:0/16:0-PA, 16:0/16:1-PA, 16:0/16:0-PA, 16:0/18:1-PA, and 16:0/18:0-PA were generated by DGK $\delta$ in C2C12 myoblast cells (Figure 3) [76].

Interestingly, we recently demonstrated that myristic acid (14:0) increased the expression of DGK $\delta$ and enhanced glucose uptake in C2C12 myotube cells $[118,119]$. Moreover, chronic oral administration of myristic acid improved hyperglycaemia by decreasing insulin-responsive glucose level in Nagoya-Shibata-Yasuda mice, a spontaneous model for studies of obese T2D [120]. These results indicate that myristic acid is a potential candidate for the prevention and therapy of T2D and its related diseases.

DGK $\delta$ is also highly enriched in the brain [121]. Recently, we generated and analyzed brain-specific DGK $\delta-K O$ mice and found that the KO mice show a selective serotonin reuptake (serotonin transporter (SERT)) inhibitor (fluoxetine)-sensitive OCD-like behaviors [122]. Moreover, the DGK $\delta$-deficiency increased the amount of SERT protein in the mouse cerebral cortex [123]. DGK $\delta$ interacted with SERT [40,123], melanoma antigen gene-D1 (MAGE-D1) [40], and Praja-1 E3 ubiquitin-protein ligase [40], which ubiquitinates SERT [124], and induced SERT degradation in a DGK activity-dependent manner [40]. It is noteworthy that only the level of 1-stearoyl-2-docosahexaenoyl (18:0/22:6)-PA was decreased in the DGK $\delta$-KO mouse brain [66], suggesting that DGK $\delta$ generates 18:0/22:6-PA in the brain. Intriguingly, 18:0/22:6-PA selectively bound to Praja-1 and enhanced its activity (see Table 1) [66]. These results indicate that DGK $\delta$ generates distinct PA species in different tissue/cells and/or in response to different stimuli. 
Table 1. PABPs and their PA species selectivity.

\begin{tabular}{|c|c|c|c|c|c|c|c|c|c|c|c|c|}
\hline \multirow{2}{*}{ Organism } & \multirow{2}{*}{ Protein } & \multicolumn{9}{|c|}{ PA Species } & \multirow{2}{*}{$\begin{array}{l}\text { Affinity }(K d) / \\
\text { PA Species }\end{array}$} & \multirow{2}{*}{ PA-Binding Region } \\
\hline & & 16:0/16:0 & 16:0/18:1 & 18:1/18:1 & 18:0/18:1 & 18:0/18:0 & 18:0/20:4 & 18:0/22:6 & Other & Mixture & & \\
\hline \multirow[t]{22}{*}{ Mammal } & $\begin{array}{l}\text { Raf-1 } \\
\text { (C-Raf) }\end{array}$ & 50 & - & 75 & - & - & - & - & $\begin{array}{c}100 \\
(16: 1 / 18: 1)\end{array}$ & - & $\begin{array}{c}78 \mathrm{nM} / \\
18: 1 / 18: 1-\mathrm{PA}\end{array}$ & FRNEVAVLRKTRHVNILLFMGYMTKDNLAIVTQWCEG \\
\hline & PKC & - & - & - & - & - & - & - & - & 100 & - & KLKLIPDPKNESKEQKTKTIRSTLN \\
\hline & PKC & - & - & - & - & - & - & - & - & 100 & - & - \\
\hline & РКС & - & 100 & - & - & - & - & - & - & - & $\begin{array}{r}20-313 \mu \mathrm{M} / \\
16: 0 / 18: 1-\mathrm{PA} \\
\end{array}$ & 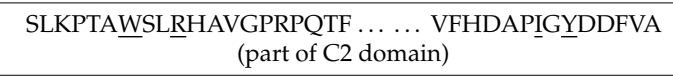 \\
\hline & PKC & - & - & - & - & - & - & - & - & 100 & - & - \\
\hline & PKN & - & - & - & - & - & - & - & - & 100 & $\begin{array}{l}15.9 \mu \mathrm{M} / \\
\text { PA mixture }\end{array}$ & - \\
\hline & mTOR & - & - & - & - & - & - & - & - & 100 & - & $\begin{array}{c}\text { RNVKGMFEVLEPLHAMMERGPQTLKETSFNQAYGRDLME } \\
\text { AQEWCRKYMKSGNVKDLTQAWDLYYHVFR }\end{array}$ \\
\hline & mTORC2 & 100 & 0 & 0 & - & - & - & - & - & - & - & - \\
\hline & Akt & - & - & - & - & - & - & - & $\begin{array}{c}100 \\
(16: 0 / 20: 4)\end{array}$ & - & - & PH domain \\
\hline & PAK1 & - & - & - & - & - & 100 & - & - & 100 & - & - \\
\hline & p70S6K1 & - & 100 & - & - & - & - & - & - & - & - & - \\
\hline & Fer & - & - & - & - & - & - & - & - & 100 & - & SMERKERLSK FESIRHSIAG \\
\hline & GRK & - & - & - & - & - & - & - & - & 100 & - & - \\
\hline & LATS1 & 100 & - & - & - & - & - & - & - & - & - & MOB binding domain, aa 601-751 \\
\hline & KSR1 & 75 & - & 75 & - & - & - & - & $\begin{array}{c}100 \\
(16: 1 / 18: 1)\end{array}$ & - & $\begin{array}{c}1.2 \mu \mathrm{M} / \\
18: 1 / 18: 1-\mathrm{PA} \\
\end{array}$ & FKKEVMNYRQTRHENVVLFMGACMNPPHLA \\
\hline & PIP5K & - & - & - & - & - & - & - & - & 100 & - & - \\
\hline & PIP5KI & - & 100 & - & - & - & - & - & - & - & - & KRPERDLMQDFYVVESIFFPSEGSNLTPAHHFQ \\
\hline & SphK1 & 100 & - & - & - & - & - & - & - & - & - & - \\
\hline & DGK & - & - & 100 & - & 30 & 100 & - & $\begin{array}{c}40 \\
(14: 0 / 14: 0)\end{array}$ & 100 & $\begin{array}{c}\text { 6-13 pmol/ } \\
\text { 18:1/18:1-PA } \\
\text { (Overlay) }\end{array}$ & RVH domain and EF-hand motifs, aa 1-259 \\
\hline & CKM & 86 & 57 & 93 & - & 100 & 14 & 14 & - & - & $\begin{array}{c}2.0 \mu \mathrm{M} / \\
16: 0 / 16: 0-\mathrm{PA} \\
\end{array}$ & - \\
\hline & SHP-1 & 100 & - & - & - & - & - & - & - & - & $\begin{array}{c}0.04 \mu \mathrm{M} / \\
16: 0 / 16: 0-\mathrm{PA}\end{array}$ & SSKHKEDVYENLHTKNKREEKVKKQRSADKEKSKGSLKRK \\
\hline & PP1c & - & - & 100 & - & - & - & - & - & - & $\begin{array}{c}1.37 \mu \mathrm{M} / \\
18: 1 / 18: 1-\mathrm{PA}\end{array}$ & $\begin{array}{l}\text { GAMMSVDETLMCSFEILKPAEKKKPNATRPVTPPRGMITK } \\
\text { QAKK }\end{array}$ \\
\hline
\end{tabular}


Table 1. Cont.

\begin{tabular}{|c|c|c|c|c|c|c|c|c|c|c|c|c|}
\hline \multirow{2}{*}{ Organism } & \multirow{2}{*}{ Protein } & \multicolumn{9}{|c|}{ PA Species } & \multirow{2}{*}{$\begin{array}{l}\text { Affinity }(K d) / \\
\text { PA Species }\end{array}$} & \multirow{2}{*}{ PA-Binding Region } \\
\hline & & 16:0/16:0 & 16:0/18:1 & 18:1/18:1 & 18:0/18:1 & 18:0/18:0 & 18:0/20:4 & 18:0/22:6 & Other & Mixture & & \\
\hline & Synaptojanin-1 & 20 & 30 & 40 & - & 30 & 100 & 100 & - & - & - & - \\
\hline & Lipin1 & - & - & - & - & - & - & - & - & 100 & - & VVKKRRKRRRKSQLDSLKR \\
\hline & PLC 1 & 89 & - & - & - & 88 & - & - & $\begin{array}{c}100 \\
(14: 0 / 14: 0)\end{array}$ & 100 & $\begin{array}{l}15 \mathrm{~mol} \% / \\
\text { PA mixture }\end{array}$ & C-terminus, aa 944-955 \\
\hline & PLC 1 & - & - & - & - & - & - & - & - & 100 & - & - \\
\hline & PLC 3 & - & - & - & - & - & - & - & - & 100 & - & - \\
\hline & PLC & - & - & - & - & - & - & - & - & 100 & $\begin{array}{l}160 \mu \mathrm{M} / \\
\text { PA mixture }\end{array}$ & - \\
\hline & Sos & - & - & - & - & - & - & - & - & 100 & $\begin{array}{l}0.2-0.5 \mu \mathrm{M} / \\
\text { PA mixture }\end{array}$ & $\begin{array}{c}\text { HF domain, aa 97-99 (RKR); PH domain, } \\
\text { aa KSNHGQPRLPGA }\end{array}$ \\
\hline & $\begin{array}{l}\text { RA-GEF-1/2 } \\
\text { (PDZ-GEF) }\end{array}$ & - & - & - & - & - & - & - & - & 100 & - & $\begin{array}{l}\text { CDC25 homology domain, aa 919-967; } \\
\text { PDZ domain, aa K428 and R429 }\end{array}$ \\
\hline & Epac1 & - & - & - & - & - & - & - & - & 100 & - & RDRKYHLRLYRQCCSGR \\
\hline & DOCK1 & - & - & - & - & - & - & - & - & 100 & - & C-terminal domain, aa 1610-1698 \\
\hline & DOCK2 & - & - & - & - & - & - & - & - & 100 & - & EYGVREMPDFEDRRVGRPRSSMRSKKRT \\
\hline & RasGAP & - & - & - & - & - & 75 & - & $\begin{array}{c}100 \\
(18: 2 / 18: 2)\end{array}$ & - & - & - \\
\hline & NF1 & - & - & - & - & - & 100 & - & - & - & $\begin{array}{c}12 \mu \mathrm{M} / \\
18: 0 / 20: 4-\mathrm{PA} \\
\end{array}$ & - \\
\hline & RacGDI & - & - & 100 & - & - & 100 & - & - & - & - & - \\
\hline & 1-Chimaerin & - & - & - & - & - & - & - & - & 100 & - & - \\
\hline & 2-Chimaerin & - & - & - & - & - & - & - & - & 100 & - & - \\
\hline & AGAP1 & - & - & - & - & - & - & - & - & 100 & - & GTP binding protein-like domain, adjacent to $\mathrm{PH}$ domain \\
\hline & ASAP1 & - & - & - & - & - & - & - & - & 100 & - & - \\
\hline & ACAP1/2 & - & - & - & - & - & - & - & - & 100 & - & - \\
\hline & ArfGAP1/2 & - & - & - & - & - & - & - & - & 100 & - & - \\
\hline & RA-RhoGAP & - & - & - & - & - & - & - & - & 100 & - & RAELKRGGLQRQERHLFLFND \\
\hline & RGS4 & - & - & - & - & - & - & - & - & 100 & $\begin{array}{l}8 \mathrm{~mol} \% / \\
\text { PA mixture }\end{array}$ & N-terminal 57 aa \\
\hline & $\operatorname{Sin} 1$ & - & - & - & - & - & - & - & - & 100 & - & PH domain \\
\hline & Arf1/6 & - & - & - & - & - & - & - & - & 100 & - & - \\
\hline
\end{tabular}


Table 1. Cont.

\begin{tabular}{|c|c|c|c|c|c|c|c|c|c|c|c|c|}
\hline \multirow{2}{*}{ Organism } & \multirow{2}{*}{ Protein } & \multicolumn{9}{|c|}{ PA Species } & \multirow{2}{*}{$\begin{array}{l}\text { Affinity }(K d) / \\
\text { PA Species }\end{array}$} & \multirow{2}{*}{ PA-Binding Region } \\
\hline & & 16:0/16:0 & 16:0/18:1 & 18:1/18:1 & 18:0/18:1 & 18:0/18:0 & 18:0/20:4 & 18:0/22:6 & Other & Mixture & & \\
\hline & Rac1 & - & - & - & - & - & - & - & $\begin{array}{c}100 \\
(14: 0 / 14: 0)\end{array}$ & - & - & AVLCPPPVKKRKKRKCLLL \\
\hline & Drp1 & 85 & - & 100 & - & - & - & - & - & - & - & Stalk domain TㅁKIIETSEL \\
\hline & PDE4A1 & - & 100 & 77 & 85 & - & - & 38 & $\begin{array}{c}69 \\
(16: 0 / 18: 2)\end{array}$ & - & $\begin{array}{c}6.8 \mu \mathrm{M} / \\
18: 0 / 18: 1-\mathrm{PA}\end{array}$ & PWLVGWWDQFKR (requires calcium) \\
\hline & PDE4A5 & 100 & 23 & - & 18 & 53 & 0 & 27 & - & - & $\begin{array}{c}1.44 \mu \mathrm{M} / \\
16: 0 / 16: 0-\mathrm{PA}\end{array}$ & - \\
\hline & PDE4B1 & - & - & - & - & - & - & - & - & 100 & - & - \\
\hline & PDE4D3 & - & - & - & - & - & - & - & - & 100 & - & DPMTSPGSGLILQANFVHSQRRESFLYRS \\
\hline & PDE4 & - & 74 & 100 & 78 & - & 94 & - & - & 89 & - & - \\
\hline & Praja-1 & - & $<5$ & 25 & - & 25 & 13 & 100 & - & - & - & - \\
\hline & p47phox & - & 100 & - & - & - & - & - & - & - & $\begin{array}{c}1.2 \mathrm{nM} / \\
16: 0 / 18: 1-\mathrm{PA}\end{array}$ & $\begin{array}{l}\text { VYRRFTEIYEFHKTLKEMFPIEAGAINPENRIIPHLPAPKWFD } \\
\text { (part of PX domain) }\end{array}$ \\
\hline & -Synuclein & 19 & 32 & 100 & - & $<5$ & 32 & - & - & - & $\begin{array}{c}6.6 \mu \mathrm{M} / \\
18: 1 / 18: 1-\mathrm{PA} \\
\end{array}$ & N-terminal 60 aa \\
\hline & LDHA & 44 & 22 & 22 & 22 & 100 & 100 & 100 & - & - & $\begin{array}{c}3.7 \mu \mathrm{M} / \\
18: 0 / 22: 6-\mathrm{PA}\end{array}$ & - \\
\hline & NF2 & 100 & - & - & - & - & - & - & - & - & - & - \\
\hline & Seipin & $<50$ & 100 & - & - & $<50$ & - & - & - & 100 & - & C2-like domain, aa 60-200 \\
\hline & CIDEA & - & - & - & - & - & - & - & $\begin{array}{c}100 \\
(12: 0 / 12: 0)\end{array}$ & - & - & C-terminal domain, RCTSFKAVLRNLLRFMS \\
\hline & $\begin{array}{c}\text { Bazooka } \\
\text { (Par-3) }\end{array}$ & 100 & - & - & - & - & - & - & - & - & - & PDZ2 domain, aa 458-546; PDZ3 domain, aa 635-682 \\
\hline & Dvl-2 & 100 & 100 & - & - & - & - & - & - & - & - & GLLKAGLIREHTVNKITFSEQ \\
\hline & RPK118 & - & - & - & - & - & - & - & - & 100 & - & $\underline{\text { KRYSDFKKLHKELW }}$ \\
\hline & Neurogranin & 100 & - & - & - & - & - & - & - & 100 & - & IQ motif, aa $29-47$ \\
\hline & $-\mathrm{COP}$ & - & - & - & - & - & - & - & - & 100 & - & - \\
\hline & NSF & - & - & - & - & - & - & - & - & 100 & - & - \\
\hline & Kinesin & - & - & - & - & - & - & - & - & 100 & - & - \\
\hline & Anc & - & - & $<5$ & - & - & - & - & - & 100 & - & - \\
\hline & Nir & - & - & - & - & - & - & - & - & 100 & - & IVAGYGSPKDVAVYAALGLSPSQTYIVGR \\
\hline
\end{tabular}


Table 1. Cont

\begin{tabular}{|c|c|c|c|c|c|c|c|c|c|c|c|c|}
\hline \multirow{2}{*}{ Organism } & \multirow{2}{*}{ Protein } & \multicolumn{9}{|c|}{ PA Species } & \multirow{2}{*}{$\begin{array}{l}\text { Affinity }(K \mathrm{~d}) / \\
\text { PA Species }\end{array}$} & \multirow{2}{*}{ PA-Binding Region } \\
\hline & & 16:0/16:0 & 16:0/18:1 & 18:1/18:1 & 18:0/18:1 & 18:0/18:0 & 18:0/20:4 & 18:0/22:6 & Other & Mixture & & \\
\hline & IQGAP1 & - & - & 100 & - & - & - & - & - & - & - & KKEKIQTGKK \\
\hline & CIN85 & - & - & - & - & - & - & - & - & 100 & - & LDEEKKIRLLRLQMEVNDIKK \\
\hline & Syntaxin1A & 100 & - & - & - & - & - & - & - & - & $\begin{array}{c}\text { EC50 } 2.0 \mathrm{pmol} / \\
\text { 16:0/16:0-PA } \\
\text { (Overlay) }\end{array}$ & DTKKAVKYQSKEARRKIMI \\
\hline & $\operatorname{CgA}$ & - & - & - & 100 & - & - & 100 & - & - & - & - \\
\hline \multirow[t]{2}{*}{ Insect } & LKB1 & - & - & - & - & - & - & - & - & 100 & - & VKKKGSALKRRAKKLTSCISVRKLSHCRTS \\
\hline & TREK-1 & - & - & - & - & - & - & - & - & 100 & $\begin{array}{c}15.7 \mu \mathrm{M} / \\
\text { PA mixture }\end{array}$ & - \\
\hline \multirow[t]{7}{*}{ Yeast } & Pah1 & $\sim 100$ & $\sim 100$ & $\sim 100$ & 100 & - & - & - & $\begin{array}{c}\sim 100 \\
(16: 0 / 18: 2) \\
\sim 100 \\
(18: 0 / 18: 2) \\
\end{array}$ & - & $\begin{array}{c}\text { Km 0.65 mol\%/ } \\
\text { 18:1/18:1-PA }\end{array}$ & - \\
\hline & Opi1p & - & 100 & 83 & 83 & - & - & 75 & $\begin{array}{c}88 \\
(16: 0 / 18: 2)\end{array}$ & 100 & $\begin{array}{c}4.5 \mu \mathrm{M} / \\
\text { 18:0/18:1-PA }\end{array}$ & $\underline{\text { KRQKLSRAIAKGKDNLKEYKLNMSIESKKR }}$ \\
\hline & Spo20p & - & 87 & 80 & 100 & - & - & 72 & $\begin{array}{c}67 \\
(16: 0 / 18: 2) \\
\end{array}$ & - & $\begin{array}{c}2.2 \mu \mathrm{M} / \\
18: 0 / 18: 1-\mathrm{PA}\end{array}$ & RLHVKLKSLRNKIHKQLH \\
\hline & Sso1p & - & 100 & - & - & - & - & - & - & - & - & KAVKSARKARRNKIIRCWLIV \\
\hline & Sec18p & - & 100 & - & - & - & - & - & - & - & $\begin{array}{c}1.4 \mu \mathrm{M} / \\
8: 0 / 8: 0-\mathrm{PA}\end{array}$ & ATP binding site (D1-D2 domain) \\
\hline & Ups1 & - & 100 & - & - & - & - & - & - & - & - & R25, K61, K155, I78, V106 \\
\hline & Chm7 & - & 100 & - & - & - & - & - & - & - & - & RKGFAKAARSAKESTNMYKSRK \\
\hline \multirow[t]{8}{*}{ Plant } & ABI1 & 0 & - & 100 & - & 10 & - & - & - & - & - & ESRKVLISRINSPNLMKESAAADIVVVDISAG \\
\hline & PP2CA & 10 & - & 100 & - & 10 & - & - & $\begin{array}{c}100 \\
(18: 2 / 18: 2) \\
\end{array}$ & 100 & - & - \\
\hline & TGD2 & - & - & - & - & - & - & - & - & 100 & $\begin{array}{l}39.6 \%(\mathrm{w} / \mathrm{w}) \\
\text { PA mixture }\end{array}$ & aa $201-225$ \\
\hline & TGD4 & - & - & 100 & - & - & - & - & - & - & - & aa $1-80,110-145$ \\
\hline & AtPDK1 & - & - & - & - & - & - & - & - & 100 & - & PH domain aa $391-491$ \\
\hline & MKK7/9 & $<10$ & 70 & 70 & 50 & 30 & - & - & - & 100 & - & - \\
\hline & SnRK2.4 & - & 100 & - & - & - & - & - & - & - & - & aa $261-302$ \\
\hline & PID & 0 & 30 & 30 & $<5$ & 0 & - & - & $\begin{array}{c}100 \\
(18: 2 / 18: 2) \\
\end{array}$ & 30 & - & LALKKKMHR \\
\hline
\end{tabular}


Table 1. Cont.

\begin{tabular}{|c|c|c|c|c|c|c|c|c|c|c|c|c|}
\hline \multirow{2}{*}{ Organism } & \multirow{2}{*}{ Protein } & \multicolumn{9}{|c|}{ PA Species } & \multirow{2}{*}{$\begin{array}{l}\text { Affinity }(K \mathrm{~d}) / \\
\text { PA Species }\end{array}$} & \multirow{2}{*}{ PA-Binding Region } \\
\hline & & 16:0/16:0 & 16:0/18:1 & 18:1/18:1 & 18:0/18:1 & 18:0/18:0 & 18:0/20:4 & 18:0/22:6 & Other & Mixture & & \\
\hline & AtSphK1 & - & - & - & - & - & - & - & - & 100 & $\begin{array}{l}0.3 \mu \mathrm{M} / \\
\text { PA mixture }\end{array}$ & VSGDGI \\
\hline & RGS1 & - & - & - & - & - & - & - & - & 100 & $\begin{array}{c}0.3 \mathrm{mM} / \\
\text { PA mixture }\end{array}$ & PLLSQISLKKK \\
\hline & PEPC & - & - & - & - & - & - & - & - & 100 & - & - \\
\hline & LHY & 80 & 30 & - & - & - & - & - & - & 100 & $\begin{array}{c}0.18 \mu \mathrm{M} / \\
16: 0 / 16: 0-\mathrm{PA}\end{array}$ & - \\
\hline & CCA1 & 100 & 30 & - & - & - & - & - & - & 30 & $\begin{array}{c}0.12 \mu \mathrm{M} / \\
16: 0 / 16: 0-\mathrm{PA}\end{array}$ & - \\
\hline & Werewolf & - & 100 & 100 & - & - & - & - & $\begin{array}{c}100 \\
(18: 2 / 18: 2) \\
\end{array}$ & 100 & $\begin{array}{c}3.99 \mu \mathrm{M} / \\
18: 1 / 18: 1-\mathrm{PA}\end{array}$ & RIAKKTGLKRCGKSCRLLRWMNYL \\
\hline & AHL4 & 0 & 100 & 100 & - & 0 & - & - & - & - & - & - \\
\hline & AKT2 & $<10$ & $<10$ & $<10$ & $<10$ & $<10$ & - & - & $\begin{array}{c}100 \\
(16: 0 / 18: 2)\end{array}$ & - & - & aa $317-855$ \\
\hline & MAP65-1 & $<5$ & 50 & 50 & 30 & $<5$ & - & - & $\begin{array}{c}100 \\
(18: 2 / 18: 2) \\
\end{array}$ & 100 & - & ARILVSKIPAM \\
\hline & RbohD160 & $<5$ & 100 & 100 & - & $<5$ & - & - & $\begin{array}{c}100 \\
(16: 0 / 18: 2)\end{array}$ & 100 & - & SRELRRVSFRRPSPAVRRFDR \\
\hline & 14-3-3 protein & - & - & - & - & - & - & - & - & 100 & $\begin{array}{l}\text { EC50 } 48.5 \mu \mathrm{M} / \\
\text { PA mixture }\end{array}$ & LSVAYKKNVIGARRASWRIIS \\
\hline & MtDef4 & 100 & 100 & 100 & - & - & - & - & $\begin{array}{c}0 \\
(8: 0 / 8: 0) \\
\end{array}$ & - & - & RGFRRR \\
\hline & NsD7 & - & - & - & - & - & - & - & - & 100 & - & DGHCSKIILRR \\
\hline & SNX & - & - & 100 & - & - & - & - & - & - & - & - \\
\hline
\end{tabular}

PA species that most strongly bind to each PABP are set to 100. PABPs that have PA species selectivity are indicated in red, and the preferred PA species are highlighted in red font. -, not determined. Amino acid residues that are critical for PA recognition are underlined. References of PABPs listed: Mammal: Raf-1 (C-Raf) [18-20], PKC $\alpha$ [125-127], PKC 8 [128],

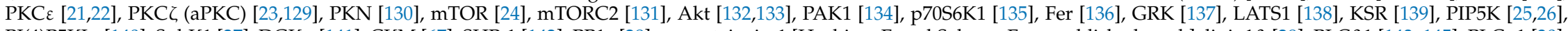
PI(4)P5KI $\gamma$ [140], SphK1 [27], DGK $\gamma$ [141], CKM [67], SHP-1 [142], PP1c [28], synaptojanin-1 [Hoshino, F. and Sakane, F., unpublished work], lipin1 $\beta$ [29], PLC $\beta 1$ [143-145], PLC $\gamma 1$ [30], PLC83 [146], PLCE [147], Sos [148], RA-GEF-1/2/PDZGEF [149,150], Epac1 [151], DOCK1 [152], DOCK2 [153], RasGAP [31], NF1 [154], RacGDI [155], $\alpha 1$-chimaerin [32], $\beta 2$-chimaerin [156], AGAP1 [157], ASAP1 [158], ACAP1/2 [159], ArfGAP1/2 [160], RA-RhoGAP [161], RGS4 [162,163], Sin1 [164], Arf1/6 [34], Rac1 [35,36], Drp1 [165], PDE4A1 [37,38], PDE4A5 [166], PDE4B1 [39], PDE4D3 [167], PDE4 [168], Praja-1 [66], p47 phox [41], $\alpha$-synuclein [42,43], LDHA [68], NF2 [138], seipin [169], CIDEA [170], Bazooka/Par-3 [171], Dvl-2 [172], RPK118 [173], neurogranin [174], $\beta$-COP [34], NSF [34], kinesin [34], Anc [175], Nir [176], IOGAP1 [177], CIN85 [178], syntaxin1A [179], CgA [180]. Insect: LKB1 [181], TREK-1 [182]. Yeast: Pah1 [183], neurogranin [174], $\beta$-COP [34], NSF [34], kinesin [34], Anc [175], Nir [176], IQGAP1 [177], CIN85 [178], syntaxin1A [179], CgA [180]. Insect: LKB1 [181], TREK-1 [182]. Yeast: Pah1 [183],
Opi1p [38,184], Spo20p [38,185,186], Sso1p [187], Sec18p [188,189], Ups1 [190,191], Chm7 [192]. Plant: ABI1 [193], PP2CA [194], TGD2 [195,196], TGD4 [197], AtPDK1 [198], MKK7/9 [199], Opi1p [38,184], Spo20p [38,185,186], Sso1p [187], Sec18p [188,189], Ups1 [190,191], Chm7 [192]. Plant: ABI1 [193], PP2CA [194], TGD2 [195,196], TGD4 [197], AtPDK1 [198], MKK7/9 [199],
SnRK2.4 [200], PID [201], AtSphK1 [202], RGS1 [203], PEPC [204], LHY [205], CCA1 [205], Werewolf [206], AHL4 [207], AKT2 [208], MAP65-1 [209], RbohD160 [210], 14-3-3 protein [211], MtDef4 [211], NsD7 [212], SNX [213]. 
It is known that docosahexaenoic acid (DHA, 22:6, $\omega-3$ ) deficiency occurs during aging and dementia and that the deficiency impairs memory and learning, exacerbates anxiety and depression, and promotes age-related neurodegenerative diseases, including Alzheimer's disease [214]. DHA is asserted to increase membrane fluidity, strengthen antioxidant activity, and plays anti-inflammatory roles [214]. However, all these effects chemically/physically, nonselectively, and indirectly affect the brain functions. On the other hand, DHA-containing PA biologically, selectively, and directly activates Praja-1 E3 ubiquitin-protein ligase and, consequently, reduces the amount of SERT protein [215], which attenuates the serotonergic system and is the target of anti-depression and anti-OCD drugs [216,217]. Therefore, it is possible that DHA incorporated into PA (and chemical compounds mimicking 18:0/22:6-PA) biologically, selectively, directly, and most effectively protect the brain dysfunctions listed above.

\section{4. $D G K \eta$}

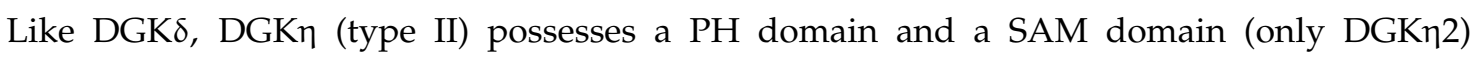

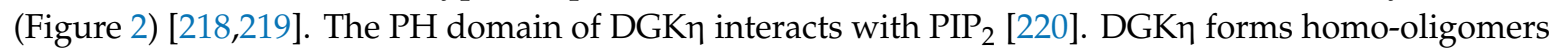
and hetero-oligomers with DGK $\delta$ via their SAM domains [219]. DGK $\eta$ is required for the Ras-B-Raf/ C-Raf-mitogen-activated protein kinase/ERK kinase (MEK)-extracellular signal-regulated kinase (ERK) signaling cascade in cancer-derived cells [221].

Successive genome-wide association studies (GWASs) indicated a possible relationship between

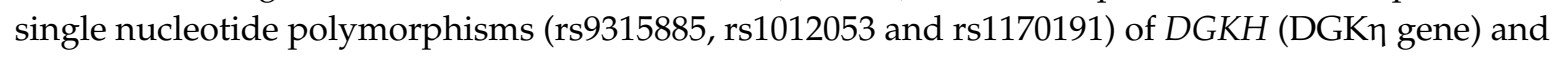
BPD [222-226]. Indeed, DGKn-KO mice exhibited BPD mania-like phenotypes [227]. Moreover, microarray analysis showed that mRNA levels of prolactin and growth hormone, which are augmented in BPD patients and BPD model animals, are most strongly increased [228]. Furthermore, it was revealed that the amount of dopamine is augmented in the DGKn-deficient mouse brain [Asami, M. and Sakane F. unpublished work]. The levels of polyunsaturated fatty acid (PUFA)-containing PA species such as 18:1/18:2-, 18:0/20:3-, 18:0/22:5-, 18:0/22:4-, and 18:0/22:3-PA were recently found to be decreased

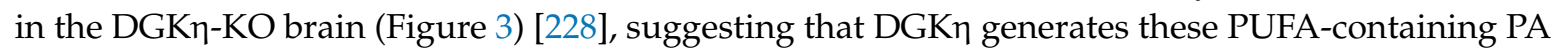
species in the brain.

\section{5. $D G K \kappa$}

DGKk, which is a type II isozyme, possesses a PH domain at the N-terminus (Figure 2) [229]. DGKк, but not other type II DGKs, is tyrosine-phosphorylated at Tyr-78 in the N-terminal, $\mathrm{k}$-isoform-specific extension through the Src family kinase pathway in response to oxidative stress [229]. Moreover, the stress inhibits DGKK activity.

It is worthy of note that Moine's group recently generated DGKK-KO mouse and revealed the relationship between DGKK and FXS [230]. FXS is caused by abnormal CGG-repeat expansion at the FMR1 gene, which codes the RNA-binding protein, fragile $X$ mental retardation protein (FMRP). Interestingly, FMRP was found to increase DGKK activity in neurons. In DGKk-deficient cortical neurons, L-quisqualic acid (a group 1 metabotropic glutamate receptor agonist)-dependent increases in 36:1 (18:0/18:1)-, 38:1 (18:0/20:1)-, and 38:2 (18:1/20:1)-PA levels were attenuated (Figure 3).

\section{6. $D G K \theta$}

DGK $\theta$ (type V) has three $\mathrm{C} 1$ domains, a glycine/proline-rich region, a Ras association domain and a PH domain-like region (Figure 2) [74]. GWAS suggested that single nucleotide polymorphisms (rs1564282 and rs11248060) of DGKQ (DGK $\theta$ gene) are associated with a higher risk of Parkinson's Disease [231,232]. DGK $\theta$ is highly expressed in the cerebellum and hippocampus in the adult rat brain [74]. Intriguingly, overexpression of DGK $\theta$ mainly increases the amount of 18:1/18:1-PA in mouse primary hepatocytes (Figure 3) [233]. It is interesting that the PA species strongly binds to $\alpha$-synuclein (see Table 1), which is associated with the pathogenesis of Parkinson's Disease (see Section 3.1) [42]. 


\section{Molecular Species Selectivity of PABP}

A number of proteins such as protein kinases, lipid kinases, protein phosphatases, lipid phosphatases, phospholipases, G-proteins, G-protein regulators, and phosphodiesterases have been identified as PABPs to date (Table 1) [11-17].

34:1 (16:0/18:1)-PA is generally abundant in mammalian cells, tissues and organs. For example, in the mouse brain, the abundance of PA species is in the order of $34: 1$ (16:0/18:1)-PA $=36: 1$ (18:0/18:1)-PA, 36:2 (18:1/18:1)-PA = 38:4 (18:0/20:4)-PA and 38:1 (18:0/20:1)-PA [228]. In mouse myoblast cells, 34:1 (16:0/18:1)-PA is most abundant, followed by 36:2 (18:1/18:1)-PA, 34:2 (16:1/18:1)-PA, 36:1 (18:0/18:1)-PA, and 32:1 (14:0/16:1)-PA [76]. Therefore, in many cases, the screening for detecting PABPs was performed with a major PA species, 16:0/18:1-PA. Moreover, because the molecular species selectivity of PABPs has not attracted attention so far, PA species mixtures were used to detect PABPs in many cases. However, as described previously, we recently found that several DGK isozymes generate diverse PA species. It is possible that the general screening with 16:0/18:1-PA and PA mixtures missed some PABPs that are selective for minor PA species. Therefore, we recently started a comprehensive screening for PABPs in the skeletal muscle and brain using several minor PA species, including 16:0/16:0-PA, which is generated by DGK $\delta$ in myoblast cells [76] and DGK $\zeta$ in neuronal cells [109], and 18:0/22:6-PA, which is produced by DGKס in the brain [66]. As a result, we found several new PABPs that have different selectivities to PA species. In addition to PA-selective PABPs discovered by us, there are only several such PABPs. Intriguingly, these PABPs do not exhibit the selectivity to 18:0/20:4-PA, which is derived from the PI turnover, indicating that they interact with PI turnover-independent PA species.

\section{1. $\alpha$-Synuclein}

$\alpha$-Synuclein has been implicated in Parkinson's Disease [234] because this protein is the main constituent of Lewy bodies in patients with the disease as well as in the bodies of patients suffering from dementia [235]. We screened 16:0/16:0-PA-binding proteins from the mouse brain and, consequently, identified $\alpha$-synuclein [42]. $\alpha$-Synuclein was already reported to be an acidic phospholipid (phosphatidylserine (PS) and PA)-binding protein [236]. However, the binding assay between $\alpha$-synuclein and acidic phospholipids has commonly employed only 16:0/18:1-PA [237-239] because this species is the major species in the brain $[228,240]$. When we determined the binding affinities of several PA species, 18:1/18:1-PA was found to much more intensely bind to $\alpha$-synuclein than 18:1/18:1-PS and 16:0/18:1-PA (Table 1) [42]. The binding intensity of 18:1/18:1-PA was also stronger than that of 16:0/16:0-PA, 18:0/18:0-PA, and 18:0/20:4-PA (Table 1). Moreover, 18:1/18:1-PA markedly induced secondary structural changes (increased $\alpha$-helix content) and aggregation formation of $\alpha$-synuclein. Therefore, 18:1/18:1-PA is likely to be the strongest binding partner of $\alpha$-synuclein among the phospholipids examined so far. Inhibitory analogs (antagonists) of 18:1/18:1-PA may slow down the progression of Parkinson's Disease via preventing aggregation formation of $\alpha$-synuclein.

As described previously, DGK $\theta$, which has been reported to be associated with the risk of Parkinson's Disease [231,232], preferentially produced 18:1/18:1-PA [233]. Interestingly, the content of PA increased in aged male mice (12-14 months old), but that of PS decreased with age [240]. Aging is the greatest risk factor for developing sporadic Parkinson's Disease [241]. Moreover, Parkinson's Disease incidence is 1.5 times higher in men than women [242,243]. Therefore, it is possible that 18:1/18:1-PA produced by DGK $\theta$ enhances the pathogenesis of Parkinson's Disease (Figure 3).

\subsection{Praja-1}

As described previously (Section 2.3), Praja-1 E3 ubiquitin-protein ligase [40] interacts with MAGE-D1, an adaptor protein for ubiquitin-dependent degradation [244] and DGK $\delta$, and ubiquitinates SERT [124]. Ubiquitinated SERT is quickly degraded in proteasomes and, consequently, the serotonergic system, especially the level of serotonin in the synaptic cleft, is upregulated. Praja-1 was recently found 
to strongly interact with 18:0/22:6-PA but not 16:0/16:0-PA, 16:0/18:1-PA, 18:1/18:1-PA, 18:0/20:4-PA, 18:0/18:0-PA or PS [66] (Table 1). Moreover, it is noteworthy that the E3 ubiquitin-protein ligase activity of Praja-1 is selectively enhanced by the DHA-containing PA, 18:0/22:6-PA, which is generated by DGK $\delta$ in the brain [66].

\subsection{Synaptojanin-1}

We screened for 18:0/22:6-PA-binding proteins in the mouse brain. As a result, synaptojanin-1 was identified [Hoshino, F. and Sakane, F., unpublished work]. Synaptojanin-1 dephosphorylates the D-5 position phosphates from $\mathrm{PI}(4,5) \mathrm{P}_{2}$ [245] and is a key player in the clathrin-mediated synaptic vesicle cycle [246]. However, it is interesting that synaptojanin-1 intensely binds to PUFA-containing-PAs, 18:0/20:4-PA and 18:0/22:6-PA (Table 1). However, the protein did not show strong binding activities for 16:0/16:0-PA, 16:0/18:1-PA, 18:1/18:1-PA, 18:0/18:0-PA, or another anionic phospholipid 18:0/22:6-PG. Therefore, it is likely that synaptojanin-1 is an 18:0/20:4-PA- and 18:0/22:6-PA-selective binding protein but not a nonselective anionic phospholipid-binding protein.

\subsection{L-Lactate Dehydrogenase (LDH) A}

LDHA in skeletal muscle is an energy-metabolizing enzyme critical for tumor-related anaerobic respiration [247]. LDHA was already reported to bind to acidic phospholipids such as PS and cardiolipin (CL), at acidic pH [248]. However, at physiological pH (7.4), 18:0/18:0-PA, 18:0/20:4-PA, and 18:0/22:6-PA more strongly interact with LDHA (Table 1) than PS or 16:0/16:0-PA [68]. Moreover, PUFA-containing PAs, 18:0/20:4-PA and 18:0/22:6-PA, but not a saturated fatty acid (SFA)-containing PA, 18:0/18:0-PA, induced secondary structural changes (decreased $\alpha$-helix content) of LDHA and attenuated its activity.

It was reported that LDHA is upregulated in human tumors, including glioblastoma [249-251]. The Warburg effect, which is the anaerobic metabolism by tumor cells even under well-oxygenated conditions, has been suggested to be an adaptive mechanism to maintain the biosynthetic requirements of uncontrolled proliferation [252]. LDHA is a key enzyme of the Warburg effect [247,253,254]. Indeed, silencing/genetic disruption of LDHA inhibited tumor growth in vitro and in vivo [255-257]. It is noteworthy that arachidonic acid (20:4)- and DHA (22:6)-containing DG were decreased within tumor regions [258]. Therefore, it is likely that a decrease of the PA molecular species containing PUFA, arachidonic acid or DHA, cannot attenuate the activity of LDHA in tumor cells. It is possible that chemical compounds that mimic 18:0/20:4-PA and 18:0/22:6-PA can be drugs against tumor cell growth.

\subsection{CKM}

CKM is also an energy metabolizing enzyme and has long been known to be correlated with T2D [259-262]. We recently identified CKM by screening using 16:0/16:0-PA liposomes and found that SFA and/or monounsaturated fatty acid (MUFA)-containing-PA species (16:0/16:0-PA, 16:0/18:1-PA, 18:1/18:1-PA and 18:0/18:0-PA) but not PUFA-containing PAs (18:0/20:4-PA or 18:0/22:6-PA) were associated with CKM [67] (Table 1). Moreover, 16:0/16:0-PA, 16:0/18:1-PA, 18:1/18:1-PA, and 18:0/18:0-PA enhanced CKM activity [68]. CKM and DGK $\delta$ coexpressed in COS-7 cells were well colocalized with each other depending on DGK $\delta$ activity [Hoshino F. and Sakane F. unpublished work]. Therefore, it is possible that a decrease in SFA/MUFA-PA species caused by the attenuated expression of DGK $\delta$ in the skeletal muscle of T2D patients [54] adversely affects the localization and activity of CKM and leads to energy metabolic failure, exacerbating T2D. It is possible that chemical compounds that mimic SFA/MUFA-PA species such as 16:0/16:0-PA, 16:0/18:1-PA, 18:1/18:1-PA, and 18:0/18:0-PA suppress the pathogenesis of T2D.

\section{6. $D G K \gamma$}

DGK $\gamma$ acts as a suppressor of Rac1-lamellipodium formation [263]. Shirai's group demonstrated, using DGK $\gamma$-KO mice, that this isozyme regulates cerebellar motor coordination, long-term depression, 
and the dendritic development of Purkinje cells [264]. Interestingly, DGK $\gamma$, a PA-producing enzyme, recursively associates with PA [141]. However, other DGK isozymes (DGK $\alpha, \beta, \delta, \eta, \kappa, \varepsilon, \zeta$, เ and $\theta$ ) failed to show such PA-binding activities. Although only protein-lipid overlay assays were performed, 18:1/18:1-PA and 18:0/20:4-PA (MUFA- or PUFA-containing PAs) more intensely bound to DGK $\gamma$ than 14:0/14:0-PA or 18:0/18:0-PA (SFA alone-containing PA) (Table 1) [141].

\subsection{Raf-1 (C-Raf)}

Raf-1 (C-Raf) kinase is a serine/threonine protein kinase and is related to a retroviral oncogene. Raf- 1 is a component of the Ras-Raf-MEK-ERK signal transduction pathway, which is involved in various growth factor-induced cell responses such as cell division. Although the effects of only three PA species were determined, Raf- 1 was found to more strongly bind to MUFA-containing PAs (16:1/18:1-PA and 18:1/18:1-PA) than a SFA alone-containing PA (16:0/16:0-PA) (Table 1) [18-20].

\section{8. mTORC2}

mTORC2, which is a rapamycin-insensitive protein complex 2 containing serine/threonine kinase mTOR, regulates cell proliferation/survival and cell migration. Although only three PA species were examined, 16:0/16:0-PA, a SFA-containing PA, much more strongly bound to mTORC2 than 16:0/18:1-PA and 18:1/18:1-PA, SFA- and/or MUFA-containing PAs (Table 1) [131].

\subsection{PDE4A1 and A5}

PDE4A1 and PDE4A5 are cAMP-specific hydrolyzing family members, which regulate cAMP-dependent signaling cascades. PDE4A1 binds more intensely to SFA-, MUFA- and/or PUFA-containing PAs, 16:0/18:1-PA, 16:0/18:2-PA, 18:1/18:1-PA, and 18:0/18:1-PA, than 18:0/22:6-PA, a DHA-containing PA (Table 1) [37,38]. PDE4A5 interacts more strongly with SFA alone-containing PAs, 16:0/16:0-PA and 18:1/18:1-PA, than MUFA- or PUFA-containing PAs, 16:0/18:1-PA, 18:0/18:1-PA, 18:0/20:4-PA and 18:0/22:6-PA (Table 1) [166].

\subsection{Seipin}

Seipin, which is an integral membrane protein in the ER, is important for lipid droplet formation. Although only a few PA species were tested, 16:0/18:1-PA, a SFA- and MUFA-containing PA, more strongly associated with seipin than 16:0/16:0-PA or 18:0/18:0-PA, SFA alone-containing PAs (Table 1) [169].

\subsection{Plant PABPs}

The PA species selectivity of plant PABPs has been well analyzed compared with mammalian PABPs. Several plant PABPs exhibit their unique PA species selectivity (Table 1). ABI1 (ABA-insensitive 1, protein phosphatase) prefers 18:1/18:1-PA [193]. LHY (late elongated hypocotyl, transcription factor involved in the circadian clock) [205] and CCA1 (circadian clock associated 1, transcription factor involved in the circadian clock) [205] strongly bind to 16:0/16:0-PA. AHL4 (AT-hook motif nuclear localized protein 4 , transcription factor to regulate triacylglycerol degradation for seeding establishment) [207] and MKK7/9 (mitogen-activated protein kinase kinase 7/9) [199] possess high affinity to 16:0/18:1-PA and 18:1/18:1-PA. Potassium channel AKT2 prefers 16:0/18:2-PA [208]. PP2CA (protein phosphatase 2CA, negative modulator of the AKT2 activity) intensely associates with 18:1/18:1-PA and 18:2/18:2-PA [194]. PID (protein kinase PINOID, regulator of auxin signaling) and MAP65-1 (microtubule-associated protein 65-1) preferentially bind to PUFA-containing PA (18:2/18:2-PA) [201]. RbohD160 (respiratory burst oxidase homolog D 160) strongly interacts with MUFA- and PUFA-containing PAs (16:0/18:1-PA, 18:1/18:1-PA and 16:0/18:2-PA) [210]. 


\section{PA Probe}

As described previously, PAs plays important physiological roles as second messengers. Therefore, tracking the localization and dynamics of intracellular PA is essential for understanding a wide variety of physiological and pathological events regulated by PA. Several PA-binding domains (PABDs), such as Spo20p-PABD [38,186] and PDE4A1-PABD [37,38], are often used as PA probes [265-267]. However, they exhibit their own subcellular localization to the plasma membrane (Spo20p-PABD) and Golgi apparatus (PDE4A1-PABD) in a cell stimulation-independent manner (a cell stimulation-induced PA generation-independent manner) $[15,38]$. The cell stimulation-independent localization disturbs their functions as PA probes and, consequently, makes them relatively difficult to apply. Therefore, a reliable and widely applicable PA probe that can be used for any cell stimulation and cell type has not been sufficiently developed to date.

In this context, $\alpha$-synuclein $\mathrm{N}$-terminal region ( $\alpha$-synuclein-PABD) is useful for PA sensing in living cells [43]. The region does not exhibit its own subcellular localization to cell membranes such as the plasma membrane and Golgi apparatus in a cell stimulation-independent manner, in contrast to PA sensors developed so far. It was confirmed that $\alpha$-synuclein-PABD was able to sense physiologically produced, endogenous PA in phagosomes [268]. Moreover, it is interesting to note that the probe detected PA at the peripheral regions (close to the plasma membrane) of neuronal growth cones [268]. $\alpha$-Synuclein-PABD strongly binds to MUFA-containing PA (18:1/18:1-PA) and only moderately interacts with SFA alone-containing and PUFA-containing PAs (Table 1) [42,43]. Therefore, $\alpha$-synucleinPABD cannot detect all PA species in cells. Thus, it is expected that PA probes selective for SFA alone-containing and PUFA-containing PAs will be developed.

\section{DG-Providing Pathway Upstream of DGK}

How do DGK isozymes produce distinct PA species? DGK isozymes, except for DGKe, have no DG species selectivity in vitro, implying that there are different upstream DG supply pathways and/or DG pools, which are independent of PI turnover and provide various DG species to each DGK isozymes. Thus, it is speculated that DG supply pathway(s) upstream of DGK provide certain DG species.

Sphingomyelin synthase-related protein (SMSr) is a six-transmembrane protein in the endoplasmic reticulum (ER), which generates DG and ceramide phosphoethanolamine (CPE) by utilizing phosphatidylethanolamine (PE) and ceramide (Figure 4) [269]. A SAM domain in SMSr form a homo-oligomer $[270,271]$. DGK $\delta$ also possesses a SAM domain and forms homo-oligomers via the domains [112,113]. Intriguingly, the SAM domains in SMSr and DGK $\delta$ are primary structurally similar to each other $[270,271]$. It is noteworthy that we recently found that SMSr and DGK $\delta$ interacted with each other through their SAM domains (Figure 4) [272]. Moreover, overexpression of both SMSr and DGK $\delta$, but not DGK $\delta$ or SMSr alone, enhanced PA production in COS-7 cells. In particular, the levels of 16:0- and/or 16:1-containing PA species including 16:1/16:1-PA, 16:0/16:1-PA, 16:0/16:0-PA, 16:1/18:1-PA, and 16:0/18:1-PA, which were also produced by DGK $\delta$ in high glucose-stimulated C2C12 myoblast cells [76], were significantly increased. Moreover, SMSr overexpressed in COS-7 cells generated 16:0and/or 16:1-containing DG species [272]. Taken together, these results strongly suggest that SMSr acts upstream of DGK $\delta$ and supplies limited species of DG to DGK $\delta$ (Figure 4). Although SMSr produces DG at the lumen side of the ER, DGK $\delta 2$ exists in the cytosol [112,113]. However, DG quickly diffuses across the lipid bilayer by the flip-flop mechanism (Figure 4) [273]. Therefore, it is likely that the DG produced by SMSr immediately transverses the ER membrane from the lumen side to the cytosol leaflet and, consequently, is provided to DGK $\delta$ (Figure 4). 


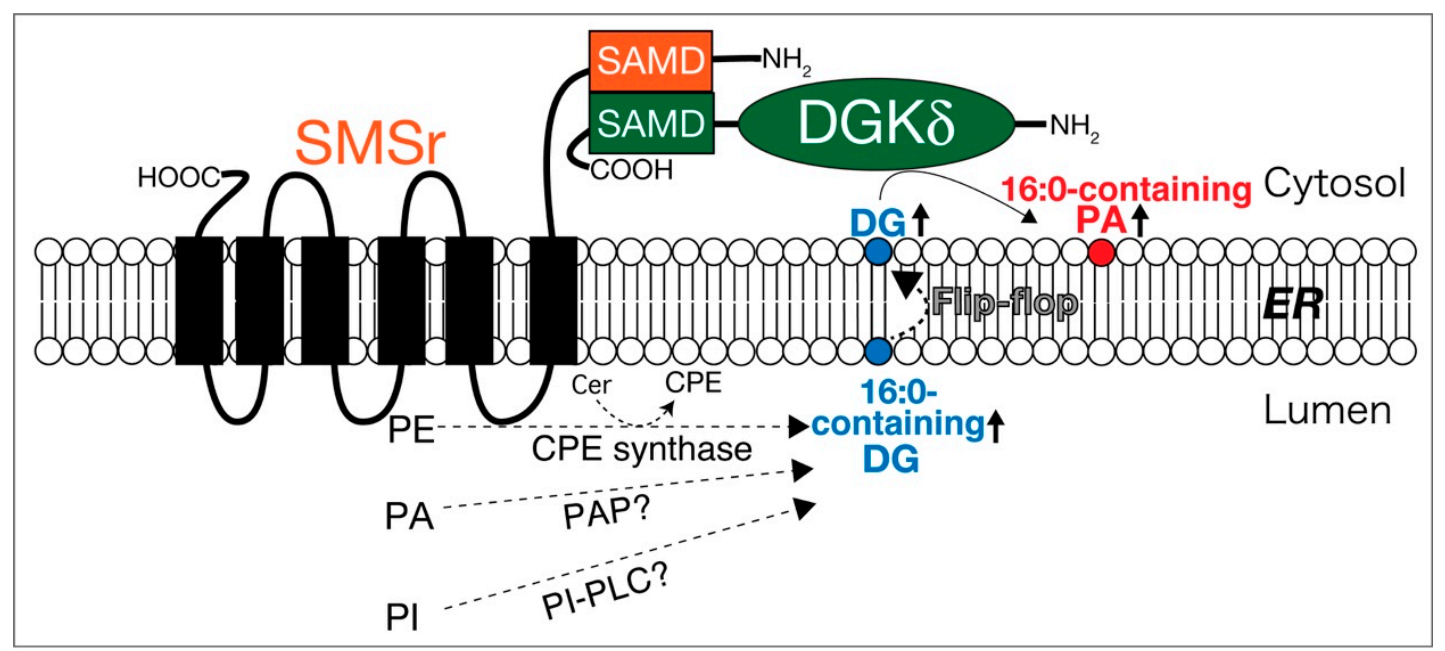

Figure 4. SMSr interacts with DGK $\delta$ and supplies DG. SAMD, SAM domain; Cer, ceramide; $\mathrm{CPE}$, ceramide phosphoethanolamine; ER, endoplasmic reticulum.

Puzzlingly, SMSr shows only slight CPE synthase activity [269]. However, it is interesting to note that, in addition to CPE synthase activity, SMSr protein, which was expressed using the baculovirus-insect cell system and highly purified, generated DG through the activities of PA phosphatase (PAP) and PI-PLC in vitro (Figure 4) [Murakami, C. and Sakane, F. unpublished work]. These activities were much stronger than the CPE synthase activity. Moreover, SMSr as PAP prefers SFA and/or MUFA-containing PA species (16:0/16:0-PA and 16:0/18:1-PA) but not PUFA-containing PA species (18:0/20:4-PA or 18:0/22:6-PA). Therefore, these results further support that the supply of DG by SMSr (PAP and PI-PLC) is independent of PI turnover.

Unlike myoblast cells [76], DG species (18:0/22:6-PA) utilized by DGK $\delta$ in the brain are not 16:0-containing DG (Figure 3) [66]. In addition to DGK $\delta$, PA species produced by DGK $\alpha$ in melanoma and $\mathrm{T}$ cells are also different from each other (Figure 3) [92,99]. The results imply that DGK isozymes utilize distinct DG-supplying pathways in different organs/tissues/cells and/or in response to different cell stimuli. DGK $\delta$ was found to interact with SMSr via the SAM domain. However, only DGK $\delta 1$, $\delta 2$, and $\eta 2$ have the SAM domain (Figure 2). Thus, other DGK isozymes lacking the SAM domain would utilize other DG-providing pathways instead of SMSr. It is urgently needed to explore other DG supply enzymes/pathways.

\section{Physiological Implication of Diversity of PA Molecular Species and PABPs}

Unlike DGBPs, which have the common DG-binding domain (the $\mathrm{C} 1$ domain), obviously common PA-binding motifs, like the $\mathrm{C} 1$ domain, have not been identified in PABPs (Table 1). The lack of communality may generate the high diversity of PABPs, which have different selectivity to PA species.

PA is the simplest glycerophospholipid. Hydrophilic head groups of PI (phosphate + inositol ring), CL (phosphate + phosphatidylglycerol (PG)), PG (phosphate + glycerol), PS (phosphate + serine), PE (phosphate + ethanolamine) and PC (phosphate + choline) are considerably larger than PA (phosphate alone). PA forms a cone-like molecular shape, rather than the cylindrical shape typical of other glycerophospholipids $[16,274]$. The shape of PA likely generates void space surrounding PA molecules. Taken together, it is speculated that PABP can easily access the fatty acid moieties of PA. If this is the case, fatty acid composition of PA would be more physiologically significant than those of other phospholipids. In contrast, DGBPs do not show obvious DG species selectivity, exemplified by PKC [275]. Because DG has only hydroxy group as the hydrophilic head, the lipid is deeply embedded in the lipid bilayer membrane. Thus, DGBPs would have difficulties accessing the fatty acid moieties of DG. However, to prove the hypothesis that PABP can easily access the fatty acid moieties 
of PA, 3D structures and molecular dynamics simulations of PABPs associated with PA molecule are further needed.

The results recently obtained suggest that DGK-PA-PABP axes can potentially construct a large and complex signaling network. DGK isozymes generate various PA species. Moreover, several PA species-selective PABPs, which regulate their related functions, have been found, and the list of PA species-selective PABPs is still growing. In addition to DGK, phospholipase D (PLD) [276] generates PA as a signaling lipid through the hydrolysis of PC (Figure 1). It has been reported that many PABPs are controlled by PLD-dependent PA [11,14-17]. Although DGK and PLD commonly generate PA, the profiles of PA species would be distinct from each other. PLD employs only PC as a substrate. On the other hand, for example, DGK $\delta$ can utilize DG species derived from PA, PI, and PE through PAP, PI-PLC and CPE synthase activities of SMSr [Murakami, C. and Sakane, F. unpublished work]. Therefore, it is likely that the variation of PA species produced by DGK is higher than that by PLD. Lysophosphatidic acid acyltransferase (LPAAT) also generates various PA species (Figure 1), which are basically utilized as precursors of various phospholipids. Interestingly, there are several LPAAT isozymes that can add different fatty acids to LPA [277-279]. PLD- and LPAAT-derived PA species, which can also bind to PA species-selective PABP, together with DGK-derived PA species would confer complexity to the PA molecular species-signaling network. The network consists of various PA producing enzymes including DGK isozymes, various PA molecular species and various PABPs and may regulate a wide variety of physiological functions and pathogenesis.

In mammals, yeasts and plants, different PA species are enriched. As previously described, in mammalian myoblast cells, 34:1 (16:0/18:1)-PA is most abundant, followed by 34:2 (16:1/18:1)-PA = 36:2 (18:1/18:1)-PA, 36:1 (18:0/18:1)-PA and 32:1 (16:0/16:1)-PA [76]. In mammalian brain, PA species are enriched in the order of 34:1 (16:0/18:1)-PA = 36:1 (18:0/18:1)-PA, 36:2 (18:1/18:1)-PA = 38:4 (18:0/20:4)-PA and 38:1 (18:0/20:1)-PA [228]. In contrast, yeast has only C16 and C18 with no or one double bond and is relatively rich in 16:1/16:1-PA and 16:1/18:1-PA [280,281]. PA species in plants are relatively double-bond rich. For example, in the model plants Arabidopsis thaliana and soybean, 34:2-PA is most abundant, followed by 34:3-PA, 36:4-PA, and 36:5-PA [282,283]. Therefore, it is likely that these organisms utilize different PA species for their cellular signaling systems and that different PA species construct distinct PA molecular species-signaling networks.

\section{Conclusions}

In addition to DG, PA is a versatile lipid second messenger. It was recently demonstrated that DGK isozymes selectively generate various PA species, which are independent of PI turnover, in isozyme-dependent and cell/stimulation-dependent manners. Moreover, there are a number of PABPs and several of them exhibit PA species selectivity. In addition, the lists of DGK isozyme-derived PA species and PABPs, especially PA species-selective PABPs, are still growing. Because PA species selectivity of only a small part of identified mammalian PABPs has been determined, the selectivity of other PABPs should be re-evaluated to explore the functions of PA species/PABPs in more detail. Most likely, many of them would show their own PA selectivity. Therefore, the recent progress in DGK and PABPs allows us to speculate that the DGK-PA-PABP axes may configure a massive network that is more complex and larger than we expect.

However, there are still many questions concerning PA and PABPs. For example, why does a variety of PA species and PABPs exist? Do PABPs most efficiently recognize fatty acid compositions? What are the upstream DG supply pathways for DGK isozymes lacking the SAM domain? Hence, we may still be in the dark in terms of PA molecular species, their generating pathways, and their molecular functions. However, there is no doubt that diversities of PA species and PABPs are key to exploring molecular mechanisms of a variety of physiological and pathological events regulated by DGK isozymes (and PLD/LPAAT). 
Author Contributions: F.S., F.H., and C.M. wrote the manuscript. All authors have read and agreed to the published version of the manuscript.

Funding: This work was supported in part by grants from MEXT/JSPS (KAKENHI Grant Numbers: 26291017 (Grant-in-Aid for Scientific Research (B)) (F.S.), 15K14470 (Grant-in-Aid for Challenging Exploratory Research) (F.S.), 17H03650 (Grant-in-Aid for Scientific Research (B) (F.S.), 20H03205 (Grant-in-Aid for Scientific Research (B) (F.S.), 18J20003 (Grant-in-Aid for JSPS Fellows) (C.M.), and 20J21133 (Grant-in-Aid for JSPS Fellows) (F.H.)); the Futaba Electronics Memorial Foundation (F.S.); the Ono Medical Research Foundation (F.S.); the Japan Foundation for Applied Enzymology (F.S.); the Food Science Institute Foundation (F.S.); the Skylark Food Science Institute (F.S.); the Asahi Group Foundation (F.S.); the Japan Milk Academic Alliance (F.S.); the Japan Food Chemical Research Foundation (F.S.); and the SENSHIN Medical Research Foundation (F.S.).

Conflicts of Interest: The authors declare no conflict of interest.

\section{Abbreviations}

$\begin{array}{ll}\text { Arf } & \text { ADP-ribosylation factor } \\ \text { aPKC } & \text { Atypical protein kinase C } \\ \text { BPD } & \text { Bipolar disorder } \\ \text { CDP-DG } & \text { Cytidine diphosphate diacylglycerol } \\ \text { CL } & \text { Cardiolipin } \\ \text { CKM } & \text { Creatine kinase-muscle type } \\ \text { CPE } & \text { Ceramide phosphoethanolamine } \\ \text { cPKC } & \text { Conventional protein kinase C } \\ \text { DG } & \text { Diacylglycerol } \\ \text { DGBP } & \text { Diacylglycerol-binding protein } \\ \text { DGK } & \text { Diacylglycerol kinase } \\ \text { DHA } & \text { Docosahexaenoic acid } \\ \text { ER } & \text { Endoplasmic reticulum } \\ \text { FMR } & \text { Fragile } \text { X mental retardation } \\ \text { FXS } & \text { Fragile } \text { X syndrome } \\ \text { GRP } & \text { Guanyl nucleotide-releasing protein } \\ \text { GWAS } & \text { Genome-wide association study } \\ \text { KO } & \text { Knockout } \\ \text { LC } & \text { Liquid chromatography } \\ \text { LDH } & \text { Lactate dehydrogenase } \\ \text { LPAAT } & \text { Lysophosphatidic acid acyltransferase } \\ \text { MARCKS } & \text { Myristoylated alanine-rich C-kinase substrate } \\ \text { MS } & \text { Mass spectrometry } \\ \text { mTOR } & \text { Mammalian target of rapamycin } \\ \text { mTORC } & \text { mTOR complex } \\ \text { MUFA } & \text { Monounsaturated fatty acid } \\ \text { nPKC } & \text { Novel protein kinase C } \\ \text { OCD } & \text { Obsessive-compulsive disorder } \\ \text { PA } & \text { Phosphatidic acid } \\ \text { PABD } & \text { Phosphatidic acid-binding domain } \\ \text { PABP } & \text { Phosphatidic acid-binding protein } \\ \text { PAP } & \text { PA phosphatase } \\ \text { PC } & \text { Phosphatidylcholine } \\ \text { PDZ } & \text { Postsynaptic density 95, discs large, zonula occludens-1 } \\ \text { PE } & \text { Phosphatidylethanolamine } \\ \text { PG } & \text { Phosphatidylglycerol } \\ \text { PI } & \text { Phosphatidylinositol } \\ \text { PIP } 2 & \text { Phosphatidylinositol 4,5-bisphosphate } \\ \text { PIP5K } & \text { PI-4-phosphate-5-kinase } \\ \text { PH } & \text { Pleckstrin homology } \\ & \end{array}$




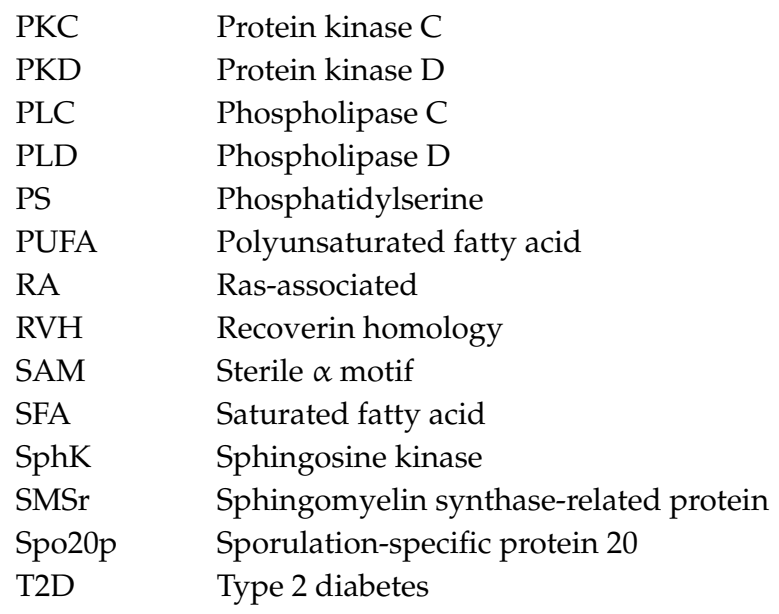

\section{References}

1. Goto, K.; Hozumi, Y.; Kondo, H. Diacylglycerol, phosphatidic acid, and the converting enzyme, diacylglycerol kinase, in the nucleus. Biochim. Biophys. Acta 2006, 1761, 535-541. [CrossRef]

2. Merida, I.; Avila-Flores, A.; Merino, E. Diacylglycerol kinases: At the hub of cell signalling. Biochem. J. 2008, 409, 1-18. [CrossRef] [PubMed]

3. Sakane, F.; Imai, S.; Kai, M.; Yasuda, S.; Kanoh, H. Diacylglycerol kinases: Why so many of them? Biochim. Biophys. Acta 2007, 1771, 793-806. [CrossRef] [PubMed]

4. Sakane, F.; Mizuno, S.; Takahashi, D.; Sakai, H. Where do substrates of diacylglycerol kinases come from? Diacylglycerol kinases utilize diacylglycerol species supplied from phosphatidylinositol turnover-independent pathways. Adv. Biol. Regul. 2018, 67, 101-108. [CrossRef] [PubMed]

5. Topham, M.K.; Epand, R.M. Mammalian diacylglycerol kinases: Molecular interactions and biological functions of selected isoforms. Biochim. Biophys. Acta 2009, 1790, 416-424. [CrossRef] [PubMed]

6. Hurley, J.H.; Newton, A.C.; Parker, P.J.; Blumberg, P.M.; Nishizuka, Y. Taxonomy and function of C1 protein kinase C homology domains. Protein Sci. 1997, 6, 477-480. [CrossRef] [PubMed]

7. Kazanietz, M.G. Novel "nonkinase" phorbol ester receptors: The C1 domain connection. Mol. Pharmacol. 2002, 61, 759-767. [CrossRef]

8. Nishizuka, Y. Intracellular signaling by hydrolysis of phospholipids and activation of protein kinase C. Science 1992, 258, 607-614. [CrossRef]

9. Ron, D.; Kazanietz, M.G. New insights into the regulation of protein kinase C and novel phorbol ester receptors. FASEB J. 1999, 13, 1658-1676. [CrossRef]

10. Ohno, S.; Nishizuka, Y. Protein kinase $C$ isotypes and their specific functions: Prologue. J. Biochem. 2002, 132, 509-511. [CrossRef]

11. Bruntz, R.C.; Lindsley, C.W.; Brown, H.A. Phospholipase D signaling pathways and phosphatidic acid as therapeutic targets in cancer. Pharmacol. Rev. 2014, 66, 1033-1079. [CrossRef] [PubMed]

12. English, D. Phosphatidic acid: A lipid messenger involved in intracellular and extracellular signalling. Cell Signal. 1996, 8, 341-347. [CrossRef]

13. Exton, J.H. Phosphatidylcholine breakdown and signal transduction. Biochim. Biophys. Acta 1994, 1212, $26-42$. [CrossRef]

14. Kim, S.C.; Wang, X. Phosphatidic acid: An emerging versatile class of cellular mediators. Essays Biochem. 2020. [CrossRef]

15. Stace, C.L.; Ktistakis, N.T. Phosphatidic acid- and phosphatidylserine-binding proteins. Biochim. Biophys. Acta 2006, 1761, 913-926. [CrossRef]

16. Zegarlinska, J.; Piascik, M.; Sikorski, A.F.; Czogalla, A. Phosphatidic acid-A simple phospholipid with multiple faces. Acta Biochim. Pol. 2018, 65, 163-171. [CrossRef]

17. Zhukovsky, M.A.; Filograna, A.; Luini, A.; Corda, D.; Valente, C. Phosphatidic acid in membrane rearrangements. FEBS Lett. 2019, 593, 2428-2451. [CrossRef] 
18. Ghosh, S.; Moore, S.; Bell, R.M.; Dush, M. Functional analysis of a phosphatidic acid binding domain in human Raf-1 kinase: Mutations in the phosphatidate binding domain lead to tail and trunk abnormalities in developing zebrafish embryos. J. Biol. Chem. 2003, 278, 45690-45696. [CrossRef]

19. Ghosh, S.; Strum, J.C.; Sciorra, V.A.; Daniel, L.; Bell, R.M. Raf-1 kinase possesses distinct binding domains for phosphatidylserine and phosphatidic acid. Phosphatidic acid regulates the translocation of Raf-1 in 12-O-tetradecanoylphorbol-13-acetate-stimulated Madin-Darby canine kidney cells. J. Biol. Chem. 1996, 271, 8472-8480. [CrossRef]

20. Rizzo, M.A.; Shome, K.; Watkins, S.C.; Romero, G. The recruitment of Raf-1 to membranes is mediated by direct interaction with phosphatidic acid and is independent of association with Ras. J. Biol. Chem. 2000, 275, 23911-23918. [CrossRef]

21. Corbalan-Garcia, S.; Sanchez-Carrillo, S.; Garcia-Garcia, J.; Gomez-Fernandez, J.C. Characterization of the membrane binding mode of the $\mathrm{C} 2$ domain of PKC . Biochemistry 2003, 42, 11661-11668. [CrossRef] [PubMed]

22. Jose Lopez-Andreo, M.; Gomez-Fernandez, J.C.; Corbalan-Garcia, S. The simultaneous production of phosphatidic acid and diacylglycerol is essential for the translocation of protein kinase $\mathrm{C} \varepsilon$ to the plasma membrane in RBL-2H3 cells. Mol. Biol. Cell 2003, 14, 4885-4895. [CrossRef] [PubMed]

23. Limatola, C.; Schaap, D.; Moolenaar, W.H.; van Blitterswijk, W.J. Phosphatidic acid activation of protein kinase $C-\zeta$ overexpressed in COS cells: Comparison with other protein kinase $C$ isotypes and other acidic lipids. Biochem. J. 1994, 304, 1001-1008. [CrossRef] [PubMed]

24. Fang, Y.; Vilella-Bach, M.; Bachmann, R.; Flanigan, A.; Chen, J. Phosphatidic acid-mediated mitogenic activation of mTOR signaling. Science 2001, 294, 1942-1945. [CrossRef] [PubMed]

25. Jenkins, G.H.; Fisette, P.L.; Anderson, R.A. Type I phosphatidylinositol 4-phosphate 5-kinase isoforms are specifically stimulated by phosphatidic acid. J. Biol. Chem. 1994, 269, 11547-11554.

26. Moritz, A.; DeGraan, P.N.E.; Gispen, W.H.; Wirtz, K.W.A. Phosphatidic acid is a specific activator of phosphatidylinositol-4-phosphate kinase. J. Biol. Chem. 1992, 267, 7207-7210.

27. Delon, C.; Manifava, M.; Wood, E.; Thompson, D.; Krugmann, S.; Pyne, S.; Ktistakis, N.T. Sphingosine kinase 1 is an intracellular effector of phosphatidic acid. J. Biol. Chem. 2004, 279, 44763-44774. [CrossRef]

28. Jones, J.A.; Hannun, Y.A. Tight binding inhibition of protein phosphatase-1 by phosphatidic acid. Specificity of inhibition by the phospholipid. J. Biol. Chem. 2002, 277, 15530-15538. [CrossRef]

29. Ren, H.; Federico, L.; Huang, H.; Sunkara, M.; Drennan, T.; Frohman, M.A.; Smyth, S.S.; Morris, A.J. A phosphatidic acid binding/nuclear localization motif determines lipin1 function in lipid metabolism and adipogenesis. Mol. Biol. Cell 2010, 21, 3171-3181. [CrossRef]

30. Jones, G.A.; Carpenter, G. The regulation of phospholipase C- $\gamma 1$ by phosphatidic acid. Assessment of kinetic parameters. J. Biol. Chem. 1993, 268, 20845-20850.

31. Tsai, M.H.; Yu, C.L.; Stacey, D.W. A cytoplasmic protein inhibits the GTPase activity of H-Ras in a phospholipid-dependent manner. Science 1990, 250, 982-985. [CrossRef]

32. Ahmed, S.; Lee, J.; Kozma, R.; Best, A.; Monfries, C.; Lim, L. A novel functional target for tumor-promoting phorbol esters and lysophosphatidic acid. The p21rac-GTPase activating protein n-chimaerin. J. Biol. Chem. 1993, 268, 10709-10712. [PubMed]

33. Caloca, M.J.; Wang, H.; Kazanietz, M.G. Characterization of the Rac-GAP (Rac-GTPase-activating protein) activity of $\beta 2$-chimaerin, a 'non-protein kinase $C^{\prime}$ phorbol ester receptor. Biochem. J. 2003, 375, 313-321. [CrossRef] [PubMed]

34. Manifava, M.; Thuring, J.W.; Lim, Z.Y.; Packman, L.; Holmes, A.B.; Ktistakis, N.T. Differential binding of traffic-related proteins to phosphatidic acid- or phosphatidylinositol (4,5)- bisphosphate-coupled affinity reagents. J. Biol. Chem. 2001, 276, 8987-8994. [CrossRef] [PubMed]

35. Chae, Y.C.; Kim, J.H.; Kim, K.L.; Kim, H.W.; Lee, H.Y.; Heo, W.D.; Meyer, T.; Suh, P.G.; Ryu, S.H. Phospholipase $\mathrm{D}$ activity regulates integrin-mediated cell spreading and migration by inducing GTP-Rac translocation to the plasma membrane. Mol. Biol. Cell 2008, 19, 3111-3123. [CrossRef]

36. Maxwell, K.N.; Zhou, Y.; Hancock, J.F. Rac1 Nanoscale Organization on the Plasma Membrane Is Driven by Lipid Binding Specificity Encoded in the Membrane Anchor. Mol. Cell. Biol. 2018, 38, e00186-18. [CrossRef] 
37. Baillie, G.S.; Huston, E.; Scotland, G.; Hodgkin, M.; Gall, I.; Peden, A.H.; MacKenzie, C.; Houslay, E.S.; Currie, R.; Pettitt, T.R.; et al. TAPAS-1, a novel microdomain within the unique N-terminal region of the PDE4A1 cAMP-specific phosphodiesterase that allows rapid, $\mathrm{Ca}^{2+}$-triggered membrane association with selectivity for interaction with phosphatidic acid. J. Biol. Chem. 2002, 277, 28298-28309. [CrossRef]

38. Kassas, N.; Tanguy, E.; Thahouly, T.; Fouillen, L.; Heintz, D.; Chasserot-Golaz, S.; Bader, M.F.; Grant, N.J.; Vitale, N. Comparative Characterization of Phosphatidic Acid Sensors and Their Localization during Frustrated Phagocytosis. J. Biol. Chem. 2017, 292, 4266-4279. [CrossRef]

39. Nemoz, G.; Sette, C.; Conti, M. Selective activation of rolipram-sensitive, cAMP-specific phosphodiesterase isoforms by phosphatidic acid. Mol. Pharmacol. 1997, 51, 242-249. [CrossRef]

40. Lu, Q.; Murakami, C.; Hoshino, F.; Murakami, Y.; Sakane, F. Diacylglycerol kinase $\delta$ destabilizes serotonin transporter protein through the ubiquitin-proteasome system. Biochim. Biophys. Acta Mol. Cell Biol. Lipids 2020, 1865, 158608. [CrossRef]

41. Karathanassis, D.; Stahelin, R.V.; Bravo, J.; Perisic, O.; Pacold, C.M.; Cho, W.; Williams, R.L. Binding of the PX domain of p47(phox) to phosphatidylinositol 3,4-bisphosphate and phosphatidic acid is masked by an intramolecular interaction. EMBO J. 2002, 21, 5057-5068. [CrossRef] [PubMed]

42. Mizuno, S.; Sasai, H.; Kume, A.; Takahashi, D.; Satoh, M.; Kado, S.; Sakane, F. Dioleoyl-phosphatidic acid selectively binds to $\alpha$-synuclein and strongly induces its aggregation. FEBS Lett. 2017, 591, 784-791. [CrossRef] [PubMed]

43. Yamada, H.; Mizuno, S.; Honda, S.; Takahashi, D.; Sakane, F. Characterization of alpha-synuclein N-terminal domain as a novel cellular phosphatidic acid sensor. FEBS J. 2020, 287, 2212-2234. [CrossRef]

44. Baldanzi, G.; Ragnoli, B.; Malerba, M. Potential role of diacylglycerol kinases in immune-mediated diseases. Clin. Sci. (Lond.) 2020, 134, 1637-1658. [CrossRef] [PubMed]

45. Goto, K.; Nakano, T.; Hozumi, Y. Diacylglycerol kinase and animal models: The pathophysiological roles in the brain and heart. Adv. Enzym. Regul. 2006, 46, 192-202. [CrossRef] [PubMed]

46. Merida, I.; Andrada, E.; Gharbi, S.I.; Avila-Flores, A. Redundant and specialized roles for diacylglycerol kinases $\alpha$ and $\zeta$ in the control of T cell functions. Sci. Signal. 2015, 8, re6. [CrossRef]

47. Sakane, F.; Imai, S.; Kai, M.; Yasuda, S.; Kanoh, H. Diacylglycerol kinases as emerging potential drug targets for a variety of diseases. Curr. Drug Targets 2008, 9, 626-640. [CrossRef]

48. Shirai, Y.; Saito, N. Diacylglycerol kinase as a possible therapeutic target for neuronal diseases. J. Biomed. Sci. 2014, 21, 28. [CrossRef]

49. Jones, D.R.; Sanjuan, M.A.; Stone, J.C.; Merida, I. Expression of a catalytically inactive form of diacylglycerol kinase $\alpha$ induces sustained signaling through RasGRP. FASEB J. 2002, 16, 595-597. [CrossRef]

50. Sanjuan, M.A.; Jones, D.R.; Izquierdo, M.; Merida, I. Role of diacylglycerol kinase $\alpha$ in the attenuation of receptor signaling. J. Cell Biol. 2001, 153, 207-220. [CrossRef]

51. Ueyama, T.; Lennartz, M.R.; Noda, Y.; Kobayashi, T.; Shirai, Y.; Rikitake, K.; Yamasaki, T.; Hayashi, S.; Sakai, N.; Seguchi, H.; et al. Superoxide production at phagosomal cup/phagosome through $\beta I$ protein kinase C during Fc $\gamma$ R-mediated phagocytosis in microglia. J. Immunol. 2004, 173, 4582-4589. [CrossRef] [PubMed]

52. Yamaguchi, Y.; Shirai, Y.; Matsubara, T.; Sanse, K.; Kuriyama, M.; Ohshiro, N.; Yoshino, K.; Yonezawa, K.; Ono, Y.; Saito, N. Phosphorylation and upregulation of diacylglycerol kinase $\gamma$ via its interaction with protein kinase C $\gamma$. J. Biol. Chem. 2006, 281, 31627-31637. [CrossRef] [PubMed]

53. Lucas, P.; Ukhanov, K.; Leinders-Zufall, T.; Zufall, F. A diacylglycerol-gated cation channel in vomeronasal neuron dendrites is impaired in TRPC2 mutant mice: Mechanism of pheromone transduction. Neuron 2003, 40, 551-561. [CrossRef]

54. Chibalin, A.V.; Leng, Y.; Vieira, E.; Krook, A.; Bjornholm, M.; Long, Y.C.; Kotova, O.; Zhong, Z.; Sakane, F.; Steiler, T.; et al. Downregulation of diacylglycerol kinase delta contributes to hyperglycemia-induced insulin resistance. Cell 2008, 132, 375-386. [CrossRef]

55. Crotty, T.; Cai, J.; Sakane, F.; Taketomi, A.; Prescott, S.M.; Topham, M.K. Diacylglycerol kinase $\delta$ regulates protein kinase $\mathrm{C}$ and epidermal growth factor receptor signaling. Proc. Natl. Acad. Sci. USA 2006, 103, 15485-15490. [CrossRef]

56. Miele, C.; Paturzo, F.; Teperino, R.; Sakane, F.; Fiory, F.; Oriente, F.; Ungaro, P.; Valentino, R.; Beguinot, F.; Formisano, P. Glucose regulates diacylglycerol intracellular levels and protein kinase $C$ activity by modulating diacylglycerol-kinase subcellular localization. J. Biol. Chem. 2007, 282, 31835-31843. [CrossRef] 
57. Luo, B.; Prescott, S.M.; Topham, M.K. Association of diacylglycerol kinase $\zeta$ with protein kinase C $\alpha$ : Spatial regulation of diacylglycerol signaling. J. Cell Biol. 2003, 160, 929-937. [CrossRef]

58. Luo, B.; Prescott, S.M.; Topham, M.K. Protein kinase $\mathrm{C} \propto$ phosphorylates and negatively regulates diacylglycerol kinase $\zeta$. J. Biol. Chem. 2003, 278, 39542-39547. [CrossRef]

59. Topham, M.K.; Prescott, S.M. Diacylglycerol kinase $\zeta$ regulates Ras activation by a novel mechanism. J. Cell Biol. 2001, 152, 1135-1144. [CrossRef]

60. Regier, D.S.; Higbee, J.; Lund, K.M.; Sakane, F.; Prescott, S.M.; Topham, M.K. Diacylglycerol kinase ı regulates Ras guanyl-releasing protein 3 and inhibits Rap1 signaling. Proc. Natl. Acad. Sci. USA 2005, 102, 7595-7600. [CrossRef]

61. Avila-Flores, A.; Santos, T.; Rincon, E.; Merida, I. Modulation of the mammalian target of rapamycin pathway by diacylglycerol kinase-produced phosphatidic acid. J. Biol. Chem. 2005, 280, 10091-10099. [CrossRef]

62. Luo, B.; Prescott, S.M.; Topham, M.K. Diacylglycerol kinase $\zeta$ regulates phosphatidylinositol 4-phosphate 5-kinase I $\alpha$ by a novel mechanism. Cell Signal. 2004, 16, 891-897. [CrossRef] [PubMed]

63. Kai, M.; Yasuda, S.; Imai, S.; Toyota, M.; Kanoh, H.; Sakane, F. Diacylglycerol kinase $\alpha$ enhances protein

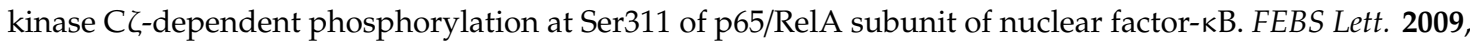
583, 3265-3268. [CrossRef] [PubMed]

64. Rainero, E.; Cianflone, C.; Porporato, P.E.; Chianale, F.; Malacarne, V.; Bettio, V.; Ruffo, E.; Ferrara, M.; Benecchia, F.; Capello, D.; et al. The diacylglycerol kinase $\alpha /$ atypical PKC/ $\beta 1$ integrin pathway in SDF- $1 \alpha$ mammary carcinoma invasiveness. PLoS ONE 2014, 9, e97144. [CrossRef]

65. Yasuda, S.; Kai, M.; Imai, S.; Kanoh, H.; Sakane, F. Diacylglycerol kinase $\gamma$ interacts with and activates 32-chimaerin, a Rac-specific GAP, in response to epidermal growth factor. FEBS Lett. 2007, 581, 551-557. [CrossRef]

66. Lu, Q.; Murakami, C.; Murakami, Y.; Hoshino, F.; Asami, M.; Usuki, T.; Sakai, H.; Sakane, F. 1-Stearoyl-2docosahexaenoyl-phosphatidic acid interacts with and activates Praja-1, the E3 ubiquitin ligase acting on the serotonin transporter in the brain. FEBS Lett. 2020, 594, 1787-1796. [CrossRef] [PubMed]

67. Hoshino, F.; Murakami, C.; Sakai, H.; Satoh, M.; Sakane, F. Creatine kinase muscle type specifically interacts with saturated fatty acid- and/or monounsaturated fatty acid-containing phosphatidic acids. Biochem. Biophys. Res. Commun. 2019, 513, 1035-1040. [CrossRef] [PubMed]

68. Hoshino, F.; Sakane, F. Polyunsaturated fatty acid-containing phosphatidic acids selectively interact with L-lactate dehydrogenase A and induce its secondary structural change and inactivation. Biochim. Biophys. Acta Mol. Cell Biol. Lipids 2020, 1865, 158768. [CrossRef]

69. Tang, W.; Bunting, M.; Zimmerman, G.A.; McIntyre, T.M.; Prescott, S.M. Molecular cloning of a novel human diacylglycerol kinase highly selective for arachidonate-containing substrates. J. Biol. Chem. 1996, 271, 10237-10241. [CrossRef] [PubMed]

70. Walsh, J.P.; Suen, R.; Lemaitre, R.N.; Glomset, J.A. Arachidonoyl-diacylglycerol kinase from bovine testis. J. Biol. Chem. 1994, 269, 21155-21164. [PubMed]

71. De Rodriguez Turco, E.B.; Tang, W.; Topham, M.K.; Sakane, F.; Marcheselli, V.L.; Chen, C.; Taketomi, A.; Prescott, S.M.; Bazan, N.G. Diacylglycerol kinase $\varepsilon$ regulates seizure susceptibility and long-term potentiation through arachidonoyl-inositol lipid signaling. Proc. Natl. Acad. Sci. USA 2001, 98, 4740-4745. [CrossRef] [PubMed]

72. Bunting, M.; Tang, W.; Zimmerman, G.A.; McIntyre, T.M.; Prescott, S.M. Molecular cloning and characterization of a novel human diacylglycerol kinase $\zeta$. J. Biol. Chem. 1996, 271, 10230-10236. [CrossRef] [PubMed]

73. Ding, L.; Traer, E.; McIntyre, T.M.; Zimmerman, G.A.; Prescott, S.M. The cloning and characterization of a novel human diacylglycerol kinase, DGKı. J. Biol. Chem. 1998, 273, 32746-32752. [CrossRef]

74. Houssa, B.; Schaap, D.; van der Val, J.; Goto, K.; Kondo, H.; Yamakawa, A.; Shibata, M.; Takenawa, T.; van Blitterswijk, W.J. Cloning of a Novel Human Diacylglycerol Kinase (DGK $\theta$ ) Containing Three Cysteine-rich Domains, a Proline-rich Region, and a Pleckstrin Homology Domain with an Overlapping Ras-associating Domain. J. Biol. Chem. 1997, 272, 10422-10428. [CrossRef] [PubMed]

75. Saito, T.; Takahashi, D.; Sakane, F. Expression, Purification, and Characterization of Human Diacylglycerol Kinase $\zeta$. ACS Omega 2019, 4, 5540-5546. [CrossRef] 
76. Sakai, H.; Kado, S.; Taketomi, A.; Sakane, F. Diacylglycerol kinase $\delta$ phosphorylates phosphatidylcholinespecific phospholipase C-dependent, palmitic acid-containing diacylglycerol species in response to high glucose levels. J. Biol. Chem. 2014, 289, 26607-26617. [CrossRef]

77. Mizuno, S.; Sakai, H.; Saito, M.; Kado, S.; Sakane, F. Diacylglycerol kinase-dependent formation of phosphatidic acid molecular species during interleukin-2 activation in CTLL-2 T-lymphocytes. FEBS Open Bio 2012, 2, 267-272. [CrossRef]

78. Sakane, F.; Yamada, K.; Kanoh, H.; Yokoyama, C.; Tanabe, T. Porcine diacylglycerol kinase sequence has zinc finger and E-F hand motifs. Nature 1990, 344, 345-348. [CrossRef]

79. Schaap, D.; de Widt, J.; van der Wal, J.; Vandekerckhove, J.; van Damme, J.; Gussow, D.; Ploegh, H.L.; van Blitterswijk, W.J.; van der Bend, R.L. Purification, cDNA-cloning and expression of human diacylglycerol kinase. FEBS Lett. 1990, 275, 151-158. [CrossRef]

80. Sakane, F.; Imai, S.; Yamada, K.; Kanoh, H. The regulatory role of EF-hand motifs of pig 80K diacylglycerol kinase as assessed using truncation and deletion mutants. Biochem. Biophys. Res. Commun. 1991, 181, 1015-1021. [CrossRef]

81. Sakane, F.; Yamada, K.; Imai, S.; Kanoh, H. Porcine 80-kDa diacylglycerol kinase is a calcium-binding and calcium/phospholipid-dependent enzyme and undergoes calcium-dependent translocation. J. Biol. Chem. 1991, 266, 7096-7100. [PubMed]

82. Takahashi, D.; Suzuki, K.; Sakamoto, T.; Iwamoto, T.; Murata, T.; Sakane, F. Crystal structure and calcium-induced conformational changes of diacylglycerol kinase $\alpha$ EF-hand domains. Protein Sci. 2019, 28, 694-706. [CrossRef]

83. Takahashi, M.; Yamamoto, T.; Sakai, H.; Sakane, F. Calcium negatively regulates an intramolecular interaction between the N-terminal recoverin homology and EF-hand motif domains and the C-terminal C1 and catalytic domains of diacylglycerol kinase $\alpha$. Biochem. Biophys. Res. Commun. 2012, 423, 571-576. [CrossRef]

84. Yamamoto, T.; Sakai, H.; Sakane, F. EF-hand motifs of diacylglycerol kinase $\alpha$ interact intra-molecularly with its C1 domains. FEBS Open Bio 2014, 4, 387-392. [CrossRef]

85. Merida, I.; Torres-Ayuso, P.; Avila-Flores, A.; Arranz-Nicolas, J.; Andrada, E.; Tello-Lafoz, M.; Liebana, R.; Arcos, R. Diacylglycerol kinases in cancer. Adv. Biol. Regul. 2017, 63, 22-31. [CrossRef]

86. Yanagisawa, K.; Yasuda, S.; Kai, M.; Imai, S.; Yamada, K.; Yamashita, T.; Jimbow, K.; Kanoh, H.; Sakane, F. Diacylglycerol kinase $\alpha$ suppresses tumor necrosis factor- $\alpha$-induced apoptosis of human melanoma cells through NF-kB activation. Biochim. Biophys. Acta 2007, 1771, 462-474. [CrossRef]

87. Takeishi, K.; Taketomi, A.; Shirabe, K.; Toshima, T.; Motomura, T.; Ikegami, T.; Yoshizumi, T.; Sakane, F.; Maehara, Y. Diacylglycerol kinase alpha enhances hepatocellular carcinoma progression by activation of Ras-Raf-MEK-ERK pathway. J. Hepatol. 2012, 57, 77-83. [CrossRef]

88. Bacchiocchi, R.; Baldanzi, G.; Carbonari, D.; Capomagi, C.; Colombo, E.; van Blitterswijk, W.J.; Graziani, A.; Fazioli, F. Activation of alpha-diacylglycerol kinase is critical for the mitogenic properties of anaplastic lymphoma kinase. Blood 2005, 106, 2175-2182. [CrossRef]

89. Baldanzi, G.; Mitola, S.; Cutrupi, S.; Filigheddu, N.; van Blitterswijk, W.J.; Sinigaglia, F.; Bussolino, F.; Graziani, A. Activation of diacylglycerol kinase $\alpha$ is required for VEGF-induced angiogenic signaling in vitro. Oncogene 2004, 23, 4828-4838. [CrossRef] [PubMed]

90. Rainero, E.; Caswell, P.T.; Muller, P.A.; Grindlay, J.; McCaffrey, M.W.; Zhang, Q.; Wakelam, M.J.; Vousden, K.H.; Graziani, A.; Norman, J.C. Diacylglycerol kinase $\alpha$ controls RCP-dependent integrin trafficking to promote invasive migration. J. Cell Biol. 2012, 196, 277-295. [CrossRef]

91. Liu, K.; Kunii, N.; Sakuma, M.; Yamaki, A.; Mizuno, S.; Sato, M.; Sakai, H.; Kado, S.; Kumagai, K.; Kojima, H.; et al. A novel diacylglycerol kinase $\alpha$-selective inhibitor, CU-3, induces cancer cell apoptosis and enhances immune response. J. Lipid Res. 2016, 57, 368-379. [CrossRef]

92. Yamaki, A.; Akiyama, R.; Murakami, C.; Takao, S.; Murakami, Y.; Mizuno, S.; Takahashi, D.; Kado, S.; Taketomi, A.; Shirai, Y.; et al. Diacylglycerol kinase $\alpha$-selective inhibitors induce apoptosis and reduce viability of melanoma and several other cancer cell lines. J. Cell. Biochem. 2019, 120, 10043-10056. [CrossRef]

93. Olenchock, B.A.; Guo, R.; Carpenter, J.H.; Jordan, M.; Topham, M.K.; Koretzky, G.A.; Zhong, X.P. Disruption of diacylglycerol metabolism impairs the induction of T cell anergy. Nat. Immunol. 2006, 7, 1174-1181. [CrossRef] [PubMed] 
94. Zha, Y.; Marks, R.; Ho, A.W.; Peterson, A.C.; Janardhan, S.; Brown, I.; Praveen, K.; Stang, S.; Stone, J.C.; Gajewski, T.F. T cell anergy is reversed by active Ras and is regulated by diacylglycerol kinase- $\alpha$. Nat. Immunol. 2006, 7, 1166-1173. [CrossRef]

95. Foell, J.; Hewes, B.; Mittler, R.S. T cell costimulatory and inhibitory receptors as therapeutic targets for inducing anti-tumor immunity. Curr. Cancer Drug Targets 2007, 7, 55-70. [CrossRef] [PubMed]

96. Prinz, P.U.; Mendler, A.N.; Masouris, I.; Durner, L.; Oberneder, R.; Noessner, E. High DGK- $\alpha$ and disabled MAPK pathways cause dysfunction of human tumor-infiltrating CD8+ T cells that is reversible by pharmacologic intervention. J. Immunol. 2012, 188, 5990-6000. [CrossRef]

97. Noessner, E. DGK- $\alpha$ : A Checkpoint in Cancer-Mediated Immuno-Inhibition and Target for Immunotherapy. Front. Cell Dev. Biol. 2017, 5, 16. [CrossRef]

98. Riese, M.J.; Moon, E.K.; Johnson, B.D.; Albelda, S.M. Diacylglycerol Kinases (DGKs): Novel Targets for Improving T Cell Activity in Cancer. Front. Cell Dev. Biol. 2016, 4, 108. [CrossRef]

99. Murakami, Y.; Murakami, C.; Hoshino, F.; Lu, Q.; Akiyama, R.; Yamaki, A.; Takahashi, D.; Sakane, F. Palmitic acid- and/or palmitoleic acid-containing phosphatidic acids are generated by diacylglycerol kinase $\alpha$ in starved Jurkat T cells. Biochem. Biophys. Res. Commun. 2020, 525, 1054-1060. [CrossRef]

100. Sakane, F.; Mizuno, S.; Komenoi, S. Diacylglycerol Kinases as Emerging Potential Drug Targets for a Variety of Diseases: An Update. Front. Cell Dev. Biol. 2016, 4, 82. [CrossRef] [PubMed]

101. Olmez, I.; Love, S.; Xiao, A.; Manigat, L.; Randolph, P.; McKenna, B.D.; Neal, B.P.; Boroda, S.; Li, M.; Brenneman, B.; et al. Targeting the mesenchymal subtype in glioblastoma and other cancers via inhibition of diacylglycerol kinase alpha. Neuro-oncology 2018, 20, 192-202. [CrossRef] [PubMed]

102. Velnati, S.; Massarotti, A.; Antona, A.; Talmon, M.; Fresu, L.G.; Galetto, A.S.; Capello, D.; Bertoni, A.; Mercalli, V.; Graziani, A.; et al. Structure activity relationship studies on Amb639752: Toward the identification of a common pharmacophoric structure for DGK $\alpha$ inhibitors. J. Enzym. Inhib. Med. Chem. 2020, 35, 96-108. [CrossRef] [PubMed]

103. Goto, K.; Kondo, H. A 104-kDa diacylglycerol kinase containing ankyrin-like repeats localizes in the cell nucleus. Proc. Natl. Acad. Sci. USA 1996, 93, 11196-11201. [CrossRef]

104. Topham, M.K.; Bunting, M.; Zimmerman, G.A.; McIntyre, T.M.; Blackshear, P.J.; Prescott, S.M. Protein kinase $C$ regulates the nuclear localization of diacylglycerol kinase- $\zeta$. Nature 1998, 394, 697-700. [CrossRef]

105. Kim, K.; Yang, J.; Zhong, X.P.; Kim, M.H.; Kim, Y.S.; Lee, H.W.; Han, S.; Choi, J.; Han, K.; Seo, J.; et al. Synaptic removal of diacylglycerol by DGK $\zeta$ and PSD-95 regulates dendritic spine maintenance. EMBO J. 2009, 28, 1170-1179. [CrossRef]

106. Yakubchyk, Y.; Abramovici, H.; Maillet, J.C.; Daher, E.; Obagi, C.; Parks, R.J.; Topham, M.K.; Gee, S.H. Regulation of neurite outgrowth in N1E-115 cells through PDZ-mediated recruitment of diacylglycerol kinase $\zeta$. Mol. Cell. Biol. 2005, 25, 7289-7302. [CrossRef] [PubMed]

107. Traynor, A.E.; Schubert, D.; Allen, W.R. Alterations of lipid metabolism in response to nerve growth factor. J. Neurochem. 1982, 39, 1677-1683. [CrossRef]

108. Traynor, A.E. The relationship between neurite extension and phospholipid metabolism in PC12 cells. Brain Res. 1984, 316, 205-210.

109. Mizuno, S.; Kado, S.; Goto, K.; Takahashi, D.; Sakane, F. Diacylglycerol kinase $\zeta$ generates dipalmitoyl-phosphatidic acid species during neuroblastoma cell differentiation. Biochem. Biophys. Rep. 2016, 8, 352-359.

110. Singh, B.K.; Kambayashi, T. The Immunomodulatory Functions of Diacylglycerol Kinase $\zeta$. Front. Cell Dev. Biol. 2016, 4, 96. [CrossRef]

111. Jung, I.Y.; Kim, Y.Y.; Yu, H.S.; Lee, M.; Kim, S.; Lee, J. CRISPR/Cas9-Mediated Knockout of DGK Improves Antitumor Activities of Human T Cells. Cancer Res. 2018, 78, 4692-4703. [CrossRef] [PubMed]

112. Sakane, F.; Imai, S.; Kai, M.; Wada, I.; Kanoh, H. Molecular cloning of a novel diacylglycerol kinase isozyme with a pleckstrin homology domain and a C-terminal tail similar to those of the EPH family of protein tyrosine kinase. J. Biol. Chem. 1996, 271, 8394-8401. [CrossRef] [PubMed]

113. Sakane, F.; Imai, S.; Yamada, K.; Murakami, T.; Tsushima, S.; Kanoh, H. Alternative splicing of the human diacylglycerol kinase $\delta$ gene generates two isoforms differing in their expression patterns and in regulatory functions. J. Biol. Chem. 2002, 277, 43519-43526. [CrossRef] 
114. Imai, S.; Kai, M.; Yamada, K.; Kanoh, H.; Sakane, F. The plasma membrane translocation of diacylglycerol kinase $\delta 1$ is negatively regulated by conventional protein kinase C-dependent phosphorylation at Ser-22 and Ser-26 within the pleckstrin homology domain. Biochem. J. 2004, 382, 957-966. [CrossRef]

115. Harada, B.T.; Knight, M.J.; Imai, S.; Qiao, F.; Ramachander, R.; Sawaya, M.R.; Gingery, M.; Sakane, F.; Bowie, J.U. Regulation of enzyme localization by polymerization: Polymer formation by the SAM domain of diacylglycerol kinase $\delta 1$. Structure 2008, 16, 380-387. [CrossRef] [PubMed]

116. Imai, S.; Sakane, F.; Kanoh, H. Phorbol ester-regulated oligomerization of diacylglycerol kinase $\delta$ linked to its phosphorylation and translocation. J. Biol. Chem. 2002, 277, 35323-35332. [CrossRef]

117. Knight, M.J.; Joubert, M.K.; Plotkowski, M.L.; Kropat, J.; Gingery, M.; Sakane, F.; Merchant, S.S.; Bowie, J.U. Zinc Binding Drives Sheet Formation by the SAM Domain of Diacylglycerol Kinase $\delta$. Biochemistry 2010, 49, 9667-9676. [CrossRef]

118. Wada, Y.; Sakiyama, S.; Sakai, H.; Sakane, F. Myristic Acid Enhances Diacylglycerol Kinase $\delta$-Dependent Glucose Uptake in Myotubes. Lipids 2016, 51, 897-903. [CrossRef]

119. Sakiyama, S.; Usuki, T.; Sakai, H.; Sakane, F. Regulation of diacylglycerol kinase $\delta 2$ expression in C2C12 skeletal muscle cells by free fatty acids. Lipids 2014, 49, 633-640. [CrossRef]

120. Takato, T.; Iwata, K.; Murakami, C.; Wada, Y.; Sakane, F. Chronic administration of myristic acid improves hyperglycaemia in the Nagoya-Shibata-Yasuda mouse model of congenital type 2 diabetes. Diabetologia 2017, 60, 2076-2083. [CrossRef]

121. Usuki, T.; Sakai, H.; Shionoya, T.; Sato, N.; Sakane, F. Expression and localization of type II diacylglycerol kinase isozymes $\delta$ and $\eta$ in the developing mouse brain. J. Histochem. Cytochem. 2015, 63, 57-68. [CrossRef] [PubMed]

122. Usuki, T.; Takato, T.; Lu, Q.; Sakai, H.; Bando, K.; Kiyonari, H.; Sakane, F. Behavioral and pharmacological phenotypes of brain-specific diacylglycerol kinase $\delta$-knockout mice. Brain Res. 2016, 1648, 193-201. [CrossRef] [PubMed]

123. Lu, Q.; Komenoi, S.; Usuki, T.; Takahashi, D.; Sakane, F. Abnormalities of the serotonergic system in diacylglycerol kinase $\delta$-deficient mouse brain. Biochem. Biophys. Res. Commun. 2018, 497, 1031-1037. [CrossRef]

124. Mouri, A.; Sasaki, A.; Watanabe, K.; Sogawa, C.; Kitayama, S.; Mamiya, T.; Miyamoto, Y.; Yamada, K.; Noda, Y.; Nabeshima, T. MAGE-D1 regulates expression of depression-like behavior through serotonin transporter ubiquitylation. J. Neurosci. 2012, 32, 4562-4580. [CrossRef]

125. Nakashima, S. Protein kinase $\mathrm{C} \propto(\mathrm{PKC} \alpha)$ : Regulation and biological function. J. Biochem. 2002, 132, 669-675. [CrossRef] [PubMed]

126. Ochoa, W.F.; Corbalan-Garcia, S.; Eritja, R.; Rodriguez-Alfaro, J.A.; Gomez-Fernandez, J.C.; Fita, I.; Verdaguer, N. Additional binding sites for anionic phospholipids and calcium ions in the crystal structures of complexes of the C2 domain of protein kinase C $\alpha$. J. Mol. Biol. 2002, 320, 277-291. [CrossRef]

127. Yokozeki, T.; Homma, K.; Kuroda, S.; Kikkawa, U.; Ohno, S.; Takahashi, M.; Imahori, K.; Kanaho, Y. Phosphatidic acid-dependent phosphorylation of a $29-\mathrm{kDa}$ protein by protein kinase Calpha in bovine brain cytosol. J. Neurochem. 1998, 71, 410-417. [CrossRef]

128. Aris, J.P.; Basta, P.V.; Holmes, W.D.; Ballas, L.M.; Moomaw, C.; Rankl, N.B.; Blobel, G.; Loomis, C.R.; Burns, D.J. Molecular and biochemical characterization of a recombinant human PKC- $\delta$ family member. Biochim. Biophys. Acta 1993, 1174, 171-181. [CrossRef]

129. Nakanishi, H.; Exton, J.H. Purification and characterization of the $\zeta$ isoform of protein kinase $C$ from bovine kidney. J. Biol. Chem. 1992, 267, 16347-16354.

130. Khan, W.A.; Blobe, G.C.; Richards, A.L.; Hannun, Y.A. Identification, partial purification, and characterization of a novel phospholipid-dependent and fatty acid-activated protein kinase from human platelets. J. Biol. Chem. 1994, 269, 9729-9735.

131. Zhang, C.; Wendel, A.A.; Keogh, M.R.; Harris, T.E.; Chen, J.; Coleman, R.A. Glycerolipid signals alter mTOR complex 2 (mTORC2) to diminish insulin signaling. Proc. Natl. Acad. Sci. USA 2012, 109, 1667-1672. [CrossRef]

132. Bruntz, R.C.; Taylor, H.E.; Lindsley, C.W.; Brown, H.A. Phospholipase D2 mediates survival signaling through direct regulation of Akt in glioblastoma cells. J. Biol. Chem. 2014, 289, 600-616. [CrossRef] [PubMed] 
133. Mahajan, K.; Coppola, D.; Challa, S.; Fang, B.; Chen, Y.A.; Zhu, W.; Lopez, A.S.; Koomen, J.; Engelman, R.W.; Rivera, C.; et al. Ack1 mediated AKT/PKB tyrosine 176 phosphorylation regulates its activation. PLoS ONE 2010, 5, e9646. [CrossRef] [PubMed]

134. Bokoch, G.M.; Reilly, A.M.; Daniels, R.H.; King, C.C.; Olivera, A.; Spiegel, S.; Knaus, U.G. A GTPase-independent mechanism of p21-activated kinase activation. Regulation by sphingosine and other biologically active lipids. J. Biol. Chem. 1998, 273, 8137-8144. [CrossRef] [PubMed]

135. Lehman, N.; Ledford, B.; Di Fulvio, M.; Frondorf, K.; McPhail, L.C.; Gomez-Cambronero, J. Phospholipase D2-derived phosphatidic acid binds to and activates ribosomal p70 S6 kinase independently of mTOR. FASEB J. 2007, 21, 1075-1087. [CrossRef]

136. Itoh, T.; Hasegawa, J.; Tsujita, K.; Kanaho, Y.; Takenawa, T. The Tyrosine Kinase Fer Is a Downstream Target of the PLD-PA Pathway that Regulates Cell Migration. Sci. Signal. 2009, 2, ra52. [CrossRef] [PubMed]

137. Debburman, S.K.; Ptasienski, J.; Boetticher, E.; Lomasney, J.W.; Benovic, J.L.; Hosey, M.M. Lipid-Mediated Regulation of G-Protein-Coupled Receptor Kinase-2 and Kinase-3. J. Biol. Chem. 1995, 270, 5742-5747. [CrossRef]

138. Han, H.; Qi, R.; Zhou, J.J.; Ta, A.P.; Yang, B.; Nakaoka, H.J.; Seo, G.; Guan, K.L.; Luo, R.; Wang, W. Regulation of the Hippo Pathway by Phosphatidic Acid-Mediated Lipid-Protein Interaction. Mol. Cell 2018, 72, 328-340.e8. [CrossRef]

139. Kraft, C.A.; Garrido, J.L.; Fluharty, E.; Leiva-Vega, L.; Romero, G. Role of phosphatidic acid in the coupling of the ERK cascade. J. Biol. Chem. 2008, 283, 36636-36645. [CrossRef]

140. Roach, A.N.; Wang, Z.; Wu, P.; Zhang, F.; Chan, R.B.; Yonekubo, Y.; Di Paolo, G.; Gorfe, A.A.; Du, G. Phosphatidic acid regulation of PIPKI is critical for actin cytoskeletal reorganization. J. Lipid Res. 2012, 53, 2598-2609. [CrossRef]

141. Takeshita, E.; Kume, A.; Maeda, Y.; Sakai, H.; Sakane, F. Diacylglycerol kinase $\gamma$ is a novel anionic phospholipid binding protein with a selective binding preference. Biochem. Biophys. Res. Commun. 2014, 444, 617-621. [CrossRef] [PubMed]

142. Frank, C.; Keilhack, H.; Opitz, F.; Zschornig, O.; Bohmer, F.D. Binding of phosphatidic acid to the protein-tyrosine phosphatase SHP-1 as a basis for activity modulation. Biochemistry 1999, 38, 11993-12002. [CrossRef] [PubMed]

143. Litosch, I. Phosphatidic acid modulates G protein regulation of phospholipase C-beta1 activity in membranes. Cell Signal. 2002, 14, 259-263. [CrossRef]

144. Litosch, I. Regulation of phospholipase C- $\beta$ activity by phosphatidic acid: Isoform dependence, role of protein kinase C, and G protein subunits. Biochemistry 2003, 42, 1618-1623. [CrossRef] [PubMed]

145. Litosch, I.; Pujari, R.; Lee, S.J. Phosphatidic acid regulates signal output by G protein coupled receptors through direct interaction with phospholipase C- $\beta 1$. Cell Signal. 2009, 21, 1379-1384. [CrossRef]

146. Pawelczyk, T.; Matecki, A. Phospholipase C- $\delta 3$ binds with high specificity to phosphatidylinositol 4,5-bisphosphate and phosphatidic acid in bilayer membranes. Eur. J. Biochem. 1999, 262, 291-298. [CrossRef] [PubMed]

147. Murthy, S.N.; Chung, P.H.; Lin, L.; Lomasney, J.W. Activation of phospholipase Cepsilon by free fatty acids and cross talk with phospholipase D and phospholipase A2. Biochemistry 2006, 45, 10987-10997. [CrossRef]

148. Zhao, C.; Du, G.; Skowronek, K.; Frohman, M.A.; Bar-Sagi, D. Phospholipase D2-generated phosphatidic acid couples EGFR stimulation to Ras activation by Sos. Nat. Cell Biol. 2007, 9, 706-712. [CrossRef]

149. Consonni, S.V.; Brouwer, P.M.; van Slobbe, E.S.; Bos, J.L. The PDZ domain of the guanine nucleotide exchange factor PDZGEF directs binding to phosphatidic acid during brush border formation. PLoS ONE 2014, 9, e98253. [CrossRef]

150. Momoi, Y.; Nishikimi, A.; Du, G.; Kataoka, T.; Katagiri, K. Phosphatidic acid regulates subcellular distribution of RA-GEFs critical for chemokine-dependent migration. Biochem. Biophys. Res. Commun. 2020, 524, 325-331. [CrossRef]

151. Consonni, S.V.; Gloerich, M.; Spanjaard, E.; Bos, J.L. cAMP regulates DEP domain-mediated binding of the guanine nucleotide exchange factor Epac1 to phosphatidic acid at the plasma membrane. Proc. Natl. Acad. Sci. USA 2012, 109, 3814-3819. [CrossRef] [PubMed]

152. Sanematsu, F.; Nishikimi, A.; Watanabe, M.; Hongu, T.; Tanaka, Y.; Kanaho, Y.; Cote, J.F.; Fukui, Y. Phosphatidic acid-dependent recruitment and function of the Rac activator DOCK1 during dorsal ruffle formation. J. Biol. Chem. 2013, 288, 8092-8100. [CrossRef] [PubMed] 
153. Nishikimi, A.; Fukuhara, H.; Su, W.; Hongu, T.; Takasuga, S.; Mihara, H.; Cao, Q.; Sanematsu, F.; Kanai, M.; Hasegawa, H.; et al. Sequential regulation of DOCK2 dynamics by two phospholipids during neutrophil chemotaxis. Science 2009, 324, 384-387. [CrossRef]

154. Bollag, G.; McCormick, F. Differential regulation of rasGAP and neurofibromatosis gene product activities. Nature 1991, 351, 576-579. [CrossRef]

155. Chuang, T.H.; Bohl, B.P.; Bokoch, G.M. Biologically active lipids are regulators of RacGDI complexation. J. Biol. Chem. 1993, 268, 26206-26211. [PubMed]

156. Caloca, M.J.; Wang, H.; Delemos, A.; Wang, S.; Kazanietz, M.G. Phorbol esters and related analogs regulate the subcellular localization of $\beta 2$-chimaerin, a non-protein kinase $C$ phorbol ester receptor. J. Biol. Chem. 2001, 276, 18303-18312. [CrossRef] [PubMed]

157. Nie, Z.; Stanley, K.T.; Stauffer, S.; Jacques, K.M.; Hirsch, D.S.; Takei, J.; Randazzo, P.A. AGAP1, an endosome-associated, phosphoinositide-dependent ADP-ribosylation factor GTPase-activating protein that affects actin cytoskeleton. J. Biol. Chem. 2002, 277, 48965-48975. [CrossRef]

158. Brown, M.T.; Andrade, J.; Radhakrishna, H.; Donaldson, J.G.; Cooper, J.A.; Randazzo, P.A. ASAP1, a phospholipid-dependent arf GTPase-activating protein that associates with and is phosphorylated by Src. Mol. Cell Biol. 1998, 18, 7038-7051. [CrossRef]

159. Jackson, T.R.; Brown, F.D.; Nie, Z.; Miura, K.; Foroni, L.; Sun, J.; Hsu, V.W.; Donaldson, J.G.; Randazzo, P.A. ACAPs are arf6 GTPase-activating proteins that function in the cell periphery. J. Cell Biol. 2000, 151, 627-638. [CrossRef]

160. Randazzo, P.A. Resolution of two ADP-ribosylation factor 1 GTPase-activating proteins from rat liver. Biochem. J. 1997, 324, 413-419. [CrossRef]

161. Kurooka, T.; Yamamoto, Y.; Takai, Y.; Sakisaka, T. Dual regulation of RA-RhoGAP activity by phosphatidic acid and Rap1 during neurite outgrowth. J. Biol. Chem. 2011, 286, 6832-6843. [CrossRef] [PubMed]

162. Ouyang, Y.S.; Tu, Y.; Barker, S.A.; Yang, F. Regulators of G-protein signaling (RGS) 4, insertion into model membranes and inhibition of activity by phosphatidic acid. J. Biol. Chem. 2003, 278, 11115-11122. [CrossRef]

163. Tu, Y.; Wilkie, T.M. Allosteric regulation of GAP activity by phospholipids in regulators of G-protein signaling. Methods Enzymol. 2004, 389, 89-105.

164. Schroder, W.A.; Buck, M.; Cloonan, N.; Hancock, J.F.; Suhrbier, A.; Sculley, T.; Bushell, G. Human Sin1 contains Ras-binding and pleckstrin homology domains and suppresses Ras signalling. Cell Signal. 2007, 19, 1279-1289. [CrossRef]

165. Adachi, Y.; Iijima, M.; Sesaki, H. An unstructured loop that is critical for interactions of the stalk domain of Drp1 with saturated phosphatidic acid. Small GTPases 2018, 9, 472-479. [CrossRef]

166. El Bawab, S.; Macovschi, O.; Sette, C.; Conti, M.; Lagarde, M.; Nemoz, G.; Prigent, A.F. Selective stimulation of a cAMP-specific phosphodiesterase (PDE4A5) isoform by phosphatidic acid molecular species endogenously formed in rat thymocytes. Eur. J. Biochem. 1997, 247, 1151-1157. [CrossRef]

167. Grange, M.; Sette, C.; Cuomo, M.; Conti, M.; Lagarde, M.; Prigent, A.F.; Nemoz, G. The cAMP-specific phosphodiesterase PDE4D3 is regulated by phosphatidic acid binding. Consequences for cAMP signaling pathway and characterization of a phosphatidic acid binding site. J. Biol. Chem. 2000, 275, 33379-33387. [CrossRef]

168. Savany, A.; Abriat, C.; Nemoz, G.; Lagarde, M.; Prigent, A.F. Activation of a cyclic nucleotide phosphodiesterase 4 (PDE4) from rat thymocytes by phosphatidic acid. Cell Signal. 1996, 8, 511-516. [CrossRef]

169. Yan, R.; Qian, H.; Lukmantara, I.; Gao, M.; Du, X.; Yan, N.; Yang, H. Human SEIPIN Binds Anionic Phospholipids. Dev. Cell 2018, 47, 248-256.e4. [CrossRef] [PubMed]

170. Barneda, D.; Planas-Iglesias, J.; Gaspar, M.L.; Mohammadyani, D.; Prasannan, S.; Dormann, D.; Han, G.S.; Jesch, S.A.; Carman, G.M.; Kagan, V.; et al. The brown adipocyte protein CIDEA promotes lipid droplet fusion via a phosphatidic acid-binding amphipathic helix. Elife 2015, 4, e07485. [CrossRef] [PubMed]

171. Yu, C.G.; Harris, T.J. Interactions between the PDZ domains of Bazooka (Par-3) and phosphatidic acid: In vitro characterization and role in epithelial development. Mol. Biol. Cell 2012, 23, 3743-3753. [CrossRef] [PubMed]

172. Capelluto, D.G.; Zhao, X.; Lucas, A.; Lemkul, J.A.; Xiao, S.; Fu, X.; Sun, F.; Bevan, D.R.; Finkielstein, C.V. Biophysical and molecular-dynamics studies of phosphatidic acid binding by the Dvl-2 DEP domain. Biophys. J. 2014, 106, 1101-1111. [CrossRef] [PubMed] 
173. Takeuchi, H.; Zhang, Z.; Gao, J.; Sugiyama, G.; Takeuchi, T.; Hirata, M. Second basic pockets contribute to the localization of PX domains by binding to phosphatidic acid. Adv. Biol. Regul. 2012, 52, 183-194. [CrossRef] [PubMed]

174. Baudier, J.; Deloulme, J.C.; Van Dorsselaer, A.; Black, D.; Matthes, H.W. Purification and characterization of a brain-specific protein kinase $C$ substrate, neurogranin ( $\mathrm{p} 17)$. Identification of a consensus amino acid sequence between neurogranin and neuromodulin (GAP43) that corresponds to the protein kinase C phosphorylation site and the calmodulin-binding domain. J. Biol. Chem. 1991, 266, 229-237.

175. Epand, R.M.; Epand, R.F.; Berno, B.; Pelosi, L.; Brandolin, G. Association of phosphatidic acid with the bovine mitochondrial ADP/ATP carrier. Biochemistry 2009, 48, 12358-12364. [CrossRef] [PubMed]

176. Kim, S.; Kedan, A.; Marom, M.; Gavert, N.; Keinan, O.; Selitrennik, M.; Laufman, O.; Lev, S. The phosphatidylinositol-transfer protein Nir2 binds phosphatidic acid and positively regulates phosphoinositide signalling. EMBO Rep. 2013, 14, 891-899. [CrossRef]

177. Wang, Z.; Cai, M.; Tay, L.W.R.; Zhang, F.; Wu, P.; Huynh, A.; Cao, X.; Di Paolo, G.; Peng, J.; Milewicz, D.M.; et al. Phosphatidic acid generated by PLD2 promotes the plasma membrane recruitment of IQGAP1 and neointima formation. FASEB J. 2019, 33, 6713-6725. [CrossRef]

178. Zheng, X.; Zhang, J.; Liao, K. The basic amino acids in the coiled-coil domain of CIN85 regulate its interaction with c-Cbl and phosphatidic acid during epidermal growth factor receptor (EGFR) endocytosis. BMC Biochem. 2014, 15, 13. [CrossRef]

179. Lam, A.D.; Tryoen-Toth, P.; Tsai, B.; Vitale, N.; Stuenkel, E.L. SNARE-catalyzed fusion events are regulated by Syntaxin1A-lipid interactions. Mol. Biol. Cell 2008, 19, 485-497. [CrossRef]

180. Carmon, O.; Laguerre, F.; Riachy, L.; Delestre-Delacour, C.; Wang, Q.; Tanguy, E.; Jeandel, L.; Cartier, D.; Thahouly, T.; Haeberle, A.M.; et al. Chromogranin A preferential interaction with Golgi phosphatidic acid induces membrane deformation and contributes to secretory granule biogenesis. FASEB J. 2020, 34, 6769-6790. [CrossRef]

181. Dogliotti, G.; Kullmann, L.; Dhumale, P.; Thiele, C.; Panichkina, O.; Mendl, G.; Houben, R.; Haferkamp, S.; Puschel, A.W.; Krahn, M.P. Membrane-binding and activation of LKB1 by phosphatidic acid is essential for development and tumour suppression. Nat. Commun. 2017, 8, 15747. [CrossRef]

182. Chung, H.W.; Petersen, E.N.; Cabanos, C.; Murphy, K.R.; Pavel, M.A.; Hansen, A.S.; Ja, W.W.; Hansen, S.B. A Molecular Target for an Alcohol Chain-Length Cutoff. J. Mol. Biol. 2019, 431, 196-209. [CrossRef] [PubMed]

183. Kwiatek, J.M.; Carman, G.M. Yeast phosphatidic acid phosphatase Pah1 hops and scoots along the membrane phospholipid bilayer. J. Lipid Res. 2020, 61, 1232-1243. [CrossRef] [PubMed]

184. Loewen, C.J.; Gaspar, M.L.; Jesch, S.A.; Delon, C.; Ktistakis, N.T.; Henry, S.A.; Levine, T.P. Phospholipid metabolism regulated by a transcription factor sensing phosphatidic acid. Science 2004, 304, 1644-1647. [CrossRef]

185. Horchani, H.; de Saint-Jean, M.; Barelli, H.; Antonny, B. Interaction of the Spo20 membrane-sensor motif with phosphatidic acid and other anionic lipids, and influence of the membrane environment. PLoS ONE 2014, 9, e113484. [CrossRef]

186. Nakanishi, H.; de los Santos, P.; Neiman, A.M. Positive and negative regulation of a SNARE protein by control of intracellular localization. Mol. Biol. Cell 2004, 15, 1802-1815. [CrossRef] [PubMed]

187. Liu, S.; Wilson, K.A.; Rice-Stitt, T.; Neiman, A.M.; McNew, J.A. In vitro fusion catalyzed by the sporulation-specific t-SNARE light-chain Spo20p is stimulated by phosphatidic acid. Traffic 2007, 8, 1630-1643. [CrossRef]

188. Starr, M.L.; Hurst, L.R.; Fratti, R.A. Phosphatidic Acid Sequesters Sec18p from cis-SNARE Complexes to Inhibit Priming. Traffic 2016, 17, 1091-1109. [CrossRef]

189. Starr, M.L.; Sparks, R.P.; Arango, A.S.; Hurst, L.R.; Zhao, Z.; Lihan, M.; Jenkins, J.L.; Tajkhorshid, E.; Fratti, R.A. Phosphatidic acid induces conformational changes in Sec18 protomers that prevent SNARE priming. J. Biol. Chem. 2019, 294, 3100-3116. [CrossRef]

190. Watanabe, Y.; Tamura, Y.; Kawano, S.; Endo, T. Structural and mechanistic insights into phospholipid transfer by Ups1-Mdm35 in mitochondria. Nat. Commun. 2015, 6, 7922. [CrossRef]

191. Yu, F.; He, F.; Yao, H.; Wang, C.; Wang, J.; Li, J.; Qi, X.; Xue, H.; Ding, J.; Zhang, P. Structural basis of intramitochondrial phosphatidic acid transport mediated by Ups1-Mdm35 complex. EMBO Rep. 2015, 16, 813-823. [CrossRef] [PubMed] 
192. Thaller, D.; Tong, D.; Marklew, C.; Borah, S.; Ciani, B.; Lusk, C.P. Direct PA-binding by Chm7 is required for nuclear envelope surveillance at herniations. bioRxiv 2020. [CrossRef]

193. Zhang, W.; Qin, C.; Zhao, J.; Wang, X. Phospholipase D $\alpha 1$-derived phosphatidic acid interacts with ABI1 phosphatase 2C and regulates abscisic acid signaling. Proc. Natl. Acad. Sci. USA 2004, 101, 9508-9513. [CrossRef] [PubMed]

194. Qu, Y.N.; Song, P.; Hu, Y.W.; Jin, X.; Jia, Q.R.; Zhang, X.D.; Chen, L.; Zhang, Q. Regulation of stomatal movement by cortical microtubule organization in response to darkness and ABA signaling in Arabidopsis. Plant Growth Regul. 2018, 84, 467-479. [CrossRef]

195. Lu, B.; Benning, C. A 25-amino acid sequence of the Arabidopsis TGD2 protein is sufficient for specific binding of phosphatidic acid. J. Biol. Chem. 2009, 284, 17420-17427. [CrossRef]

196. Roston, R.; Gao, J.; Xu, C.; Benning, C. Arabidopsis chloroplast lipid transport protein TGD2 disrupts membranes and is part of a large complex. Plant J. 2011, 66, 759-769. [CrossRef] [PubMed]

197. Wang, Z.; Anderson, N.S.; Benning, C. The phosphatidic acid binding site of the Arabidopsis trigalactosyldiacylglycerol 4 (TGD4) protein required for lipid import into chloroplasts. J. Biol. Chem. 2013, 288, 4763-4771. [CrossRef]

198. Anthony, R.G.; Henriques, R.; Helfer, A.; Meszaros, T.; Rios, G.; Testerink, C.; Munnik, T.; Deak, M.; Koncz, C.; Bogre, L. A protein kinase target of a PDK1 signalling pathway is involved in root hair growth in Arabidopsis. EMBO J. 2004, 23, 572-581. [CrossRef] [PubMed]

199. Shen, L.; Zhuang, B.; Wu, Q.; Zhang, H.; Nie, J.; Jing, W.; Yang, L.; Zhang, W. Phosphatidic acid promotes the activation and plasma membrane localization of MKK7 and MKK9 in response to salt stress. Plant Sci. 2019, 287, 110190. [CrossRef]

200. Julkowska, M.M.; McLoughlin, F.; Galvan-Ampudia, C.S.; Rankenberg, J.M.; Kawa, D.; Klimecka, M.; Haring, M.A.; Munnik, T.; Kooijman, E.E.; Testerink, C. Identification and functional characterization of the Arabidopsis Snf1-related protein kinase SnRK2.4 phosphatidic acid-binding domain. Plant Cell Environ. 2015, 38, 614-624. [CrossRef]

201. Wang, P.; Shen, L.; Guo, J.; Jing, W.; Qu, Y.; Li, W.; Bi, R.; Xuan, W.; Zhang, Q.; Zhang, W. Phosphatidic Acid Directly Regulates PINOID-Dependent Phosphorylation and Activation of the PIN-FORMED2 Auxin Efflux Transporter in Response to Salt Stress. Plant Cell 2019, 31, 250-271. [CrossRef] [PubMed]

202. Pandit, S.; Dalal, V.; Mishra, G. Identification of novel phosphatidic acid binding domain on sphingosine kinase 1 of Arabidopsis thaliana. Plant Physiol. Biochem. 2018, 128, 178-184. [CrossRef] [PubMed]

203. Roy Choudhury, S.; Pandey, S. Phosphatidic acid binding inhibits RGS1 activity to affect specific signaling pathways in Arabidopsis. Plant J. 2017, 90, 466-477. [CrossRef] [PubMed]

204. Testerink, C.; Dekker, H.L.; Lim, Z.Y.; Johns, M.K.; Holmes, A.B.; Koster, C.G.; Ktistakis, N.T.; Munnik, T. Isolation and identification of phosphatidic acid targets from plants. Plant J. 2004, 39, 527-536. [CrossRef]

205. Kim, S.C.; Nusinow, D.A.; Sorkin, M.L.; Pruneda-Paz, J.; Wang, X. Interaction and Regulation Between Lipid Mediator Phosphatidic Acid and Circadian Clock Regulators. Plant Cell 2019, 31, 399-416. [CrossRef]

206. Yao, H.; Wang, G.; Guo, L.; Wang, X. Phosphatidic acid interacts with a MYB transcription factor and regulates its nuclear localization and function in Arabidopsis. Plant Cell 2013, 25, 5030-5042. [CrossRef]

207. Cai, G.; Kim, S.C.; Li, J.; Zhou, Y.; Wang, X. Transcriptional Regulation of Lipid Catabolism during Seedling Establishment. Mol. Plant 2020, 13, 984-1000. [CrossRef]

208. Shen, L.; Tian, Q.; Yang, L.; Zhang, H.; Shi, Y.; Shen, Y.; Zhou, Z.; Wu, Q.; Zhang, Q.; Zhang, W. Phosphatidic acid directly binds with rice potassium channel OsAKT2 to inhibit its activity. Plant J. 2020, 102, 649-665. [CrossRef]

209. Zhang, Q.; Lin, F.; Mao, T.; Nie, J.; Yan, M.; Yuan, M.; Zhang, W. Phosphatidic acid regulates microtubule organization by interacting with MAP65-1 in response to salt stress in Arabidopsis. Plant Cell 2012, 24, 4555-4576. [CrossRef]

210. Zhang, Y.; Zhu, H.; Zhang, Q.; Li, M.; Yan, M.; Wang, R.; Wang, L.; Welti, R.; Zhang, W.; Wang, X. Phospholipase $\mathrm{D} \alpha 1$ and phosphatidic acid regulate NADPH oxidase activity and production of reactive oxygen species in ABA-mediated stomatal closure in Arabidopsis. Plant Cell 2009, 21, 2357-2377. [CrossRef]

211. Sagaram, U.S.; El-Mounadi, K.; Buchko, G.W.; Berg, H.R.; Kaur, J.; Pandurangi, R.S.; Smith, T.J.; Shah, D.M. Structural and functional studies of a phosphatidic acid-binding antifungal plant defensin MtDef4: Identification of an RGFRRR motif governing fungal cell entry. PLoS ONE 2013, 8, e82485. [CrossRef] 
212. Kvansakul, M.; Lay, F.T.; Adda, C.G.; Veneer, P.K.; Baxter, A.A.; Phan, T.K.; Poon, I.K.; Hulett, M.D. Binding of phosphatidic acid by NsD7 mediates the formation of helical defensin-lipid oligomeric assemblies and membrane permeabilization. Proc. Natl. Acad. Sci. USA 2016, 113, 11202-11207. [CrossRef] [PubMed]

213. Lin, D.L.; Yao, H.Y.; Jia, L.H.; Tan, J.F.; Xu, Z.H.; Zheng, W.M.; Xue, H.W. Phospholipase D-derived phosphatidic acid promotes root hair development under phosphorus deficiency by suppressing vacuolar degradation of PIN-FORMED2. New Phytol. 2020, 226, 142-155. [CrossRef] [PubMed]

214. Hashimoto, M.; Hossain, S.; Al Mamun, A.; Matsuzaki, K.; Arai, H. Docosahexaenoic acid: One molecule diverse functions. Crit. Rev. Biotechnol. 2017, 37, 579-597. [CrossRef]

215. Meneses, A.; Liy-Salmeron, G. Serotonin and emotion, learning and memory. Rev. Neurosci. 2012, 23, $543-553$. [CrossRef]

216. Joel, D. Current animal models of obsessive compulsive disorder: A critical review. Prog. Neuro Psychopharmacol. Biol. Psychiatry 2006, 30, 374-388. [CrossRef]

217. Yadin, E.; Friedman, E.; Bridger, W.H. Spontaneous alternation behavior: An animal model for obsessivecompulsive disorder? Pharmacol. Biochem. Behav. 1991, 40, 311-315. [CrossRef]

218. Klauck, T.M.; Xu, X.; Mousseau, B.; Jaken, S. Cloning and characterization of a glucocorticoid-induced diacylglycerol kinase. J. Biol. Chem. 1996, 271, 19781-19788. [CrossRef]

219. Murakami, T.; Sakane, F.; Imai, S.; Houkin, K.; Kanoh, H. Identification and characterization of two splice variants of human diacylglycerol kinase $\eta$. J. Biol. Chem. 2003, 278, 34364-34372. [CrossRef]

220. Kume, A.; Kawase, K.; Komenoi, S.; Usuki, T.; Takeshita, E.; Sakai, H.; Sakane, F. The Pleckstrin Homology Domain of Diacylglycerol Kinase eta Strongly and Selectively Binds to Phosphatidylinositol 4,5-Bisphosphate. J. Biol. Chem. 2016, 291, 8150-8161. [CrossRef] [PubMed]

221. Yasuda, S.; Kai, M.; Imai, S.; Takeishi, K.; Taketomi, A.; Toyota, M.; Kanoh, H.; Sakane, F. Diacylglycerol kinase $\eta$ augments C-Raf activity and B-Raf/C-Raf heterodimerization. J. Biol. Chem. 2009, 284, 29559-29570. [CrossRef]

222. Baum, A.E.; Akula, N.; Cabanero, M.; Cardona, I.; Corona, W.; Klemens, B.; Schulze, T.G.; Cichon, S.; Rietschel, M.; Nothen, M.M.; et al. A genome-wide association study implicates diacylglycerol kinase eta (DGKH) and several other genes in the etiology of bipolar disorder. Mol. Psychiatry 2008, 13, 197-207. [CrossRef] [PubMed]

223. Ollila, H.M.; Soronen, P.; Silander, K.; Palo, O.M.; Kieseppa, T.; Kaunisto, M.A.; Lonnqvist, J.; Peltonen, L.; Partonen, T.; Paunio, T. Findings from bipolar disorder genome-wide association studies replicate in a Finnish bipolar family-cohort. Mol. Psychiatry 2009, 14, 351-353. [CrossRef] [PubMed]

224. Squassina, A.; Manchia, M.; Congiu, D.; Severino, G.; Chillotti, C.; Ardau, R.; Piccardi, M.; Zompo, M.D. The diacylglycerol kinase eta gene and bipolar disorder: A replication study in a Sardinian sample. Mol. Psychiatry 2009, 14, 350-351. [CrossRef] [PubMed]

225. Weber, H.; Kittel-Schneider, S.; Gessner, A.; Domschke, K.; Neuner, M.; Jacob, C.P.; Buttenschon, H.N.; Boreatti-Hummer, A.; Volkert, J.; Herterich, S.; et al. Cross-disorder analysis of bipolar risk genes: Further evidence of DGKH as a risk gene for bipolar disorder, but also unipolar depression and adult ADHD. Neuropsychopharmacol. Off. Publ. Am. Coll. Neuropsychopharmacol. 2011, 36, 2076-2085. [CrossRef] [PubMed]

226. Zeng, Z.; Wang, T.; Li, T.; Li, Y.; Chen, P.; Zhao, Q.; Liu, J.; Li, J.; Feng, G.; He, L.; et al. Common SNPs and haplotypes in DGKH are associated with bipolar disorder and schizophrenia in the Chinese Han population. Mol. Psychiatry 2011, 16, 473-475. [CrossRef]

227. Isozaki, T.; Komenoi, S.; Lu, Q.; Usuki, T.; Tomokata, S.; Matsutomo, D.; Sakai, H.; Bando, K.; Kiyonari, H.; Sakane, F. Deficiency of diacylglycerol kinase $\eta$ induces lithium-sensitive mania-like behavior. J. Neurochem. 2016, 138, 448-456. [CrossRef]

228. Komenoi, S.; Suzuki, Y.; Asami, M.; Murakami, C.; Hoshino, F.; Chiba, S.; Takahashi, D.; Kado, S.; Sakane, F. Microarray analysis of gene expression in the diacylglycerol kinase $\eta$ knockout mouse brain. Biochem. Biophys. Rep. 2019, 19, 100660. [CrossRef]

229. Imai, S.; Kai, M.; Yasuda, S.; Kanoh, H.; Sakane, F. Identification and characterization of a novel human type II diacylglycerol kinase, DGKk. J. Biol. Chem. 2005, 280, 39870-39881. [CrossRef]

230. Tabet, R.; Moutin, E.; Becker, J.A.; Heintz, D.; Fouillen, L.; Flatter, E.; Krezel, W.; Alunni, V.; Koebel, P.; Dembele, D.; et al. Fragile X Mental Retardation Protein (FMRP) controls diacylglycerol kinase activity in neurons. Proc. Natl. Acad. Sci. USA 2016, 113, E3619-E3628. [CrossRef] 
231. Pankratz, N.; Wilk, J.B.; Latourelle, J.C.; DeStefano, A.L.; Halter, C.; Pugh, E.W.; Doheny, K.F.; Gusella, J.F.; Nichols, W.C.; Foroud, T.; et al. Genomewide association study for susceptibility genes contributing to familial Parkinson disease. Hum. Genet. 2009, 124, 593-605. [CrossRef] [PubMed]

232. Simon-Sanchez, J.; van Hilten, J.J.; van de Warrenburg, B.; Post, B.; Berendse, H.W.; Arepalli, S.; Hernandez, D.G.; de Bie, R.M.; Velseboer, D.; Scheffer, H.; et al. Genome-wide association study confirms extant PD risk loci among the Dutch. Eur. J. Hum. Genet. EJHG 2011, 19, 655-661. [CrossRef] [PubMed]

233. Zhang, C.; Hwarng, G.; Cooper, D.E.; Grevengoed, T.J.; Eaton, J.M.; Natarajan, V.; Harris, T.E.; Coleman, R.A. Inhibited insulin signaling in mouse hepatocytes is associated with increased phosphatidic acid but not diacylglycerol. J. Biol. Chem. 2015, 290, 3519-3528. [CrossRef] [PubMed]

234. Ruiperez, V.; Darios, F.; Davletov, B. Alpha-synuclein, lipids and Parkinson's disease. Prog. Lipid Res. 2010, 49, 420-428. [CrossRef] [PubMed]

235. Spillantini, M.G.; Schmidt, M.L.; Lee, V.M.; Trojanowski, J.Q.; Jakes, R.; Goedert, M. $\alpha$-synuclein in Lewy bodies. Nature 1997, 388, 839-840. [CrossRef]

236. Kubo, S.; Nemani, V.M.; Chalkley, R.J.; Anthony, M.D.; Hattori, N.; Mizuno, Y.; Edwards, R.H.; Fortin, D.L. A combinatorial code for the interaction of $\alpha$-synuclein with membranes. J. Biol. Chem. 2005, 280, 31664-31672. [CrossRef]

237. Bussell, R., Jr.; Eliezer, D. Effects of Parkinson's disease-linked mutations on the structure of lipid-associated $\alpha$-synuclein. Biochemistry 2004, 43, 4810-4818. [CrossRef]

238. Davidson, W.S.; Jonas, A.; Clayton, D.F.; George, J.M. Stabilization of $\alpha$-synuclein secondary structure upon binding to synthetic membranes. J. Biol. Chem. 1998, 273, 9443-9449. [CrossRef]

239. Jiang, Z.; Hess, S.K.; Heinrich, F.; Lee, J.C. Molecular details of $\alpha$-synuclein membrane association revealed by neutrons and photons. J. Phys. Chem. B 2015, 119, 4812-4823. [CrossRef]

240. Rappley, I.; Myers, D.S.; Milne, S.B.; Ivanova, P.T.; Lavoie, M.J.; Brown, H.A.; Selkoe, D.J. Lipidomic profiling in mouse brain reveals differences between ages and genders, with smaller changes associated with $\alpha$-synuclein genotype. J. Neurochem. 2009, 111, 15-25. [CrossRef]

241. Reeve, A.; Simcox, E.; Turnbull, D. Ageing and Parkinson's disease: Why is advancing age the biggest risk factor? Ageing Res. Rev. 2014, 14, 19-30. [CrossRef] [PubMed]

242. Taylor, K.S.; Cook, J.A.; Counsell, C.E. Heterogeneity in male to female risk for Parkinson's disease. J. Neurol. Neurosurg. Psychiatry 2007, 78, 905-906. [CrossRef]

243. Wooten, G.F.; Currie, L.J.; Bovbjerg, V.E.; Lee, J.K.; Patrie, J. Are men at greater risk for Parkinson's disease than women? J. Neurol. Neurosurg. Psychiatry 2004, 75, 637-639. [CrossRef] [PubMed]

244. Sasaki, A.; Masuda, Y.; Iwai, K.; Ikeda, K.; Watanabe, K. A RING finger protein Praja1 regulates Dlx5-dependent transcription through its ubiquitin ligase activity for the Dlx/Msx-interacting MAGE/Necdin family protein, Dlxin-1. J. Biol. Chem. 2002, 277, 22541-22546. [CrossRef] [PubMed]

245. McPherson, P.S.; Garcia, E.P.; Slepnev, V.I.; David, C.; Zhang, X.; Grabs, D.; Sossin, W.S.; Bauerfeind, R.; Nemoto, Y.; De Camilli, P. A presynaptic inositol-5-phosphatase. Nature 1996, 379, 353-357. [CrossRef] [PubMed]

246. Montesinos, M.L.; Castellano-Munoz, M.; Garcia-Junco-Clemente, P.; Fernandez-Chacon, R. Recycling and EH domain proteins at the synapse. Brain Res. Brain Res. Rev. 2005, 49, 416-428. [CrossRef]

247. Augoff, K.; Hryniewicz-Jankowska, A.; Tabola, R. Lactate dehydrogenase 5: An old friend and a new hope in the war on cancer. Cancer Lett. 2015, 358, 1-7. [CrossRef]

248. Terlecki, G.; Czapinska, E.; Rogozik, K.; Lisowski, M.; Gutowicz, J. Investigation of the interaction of pig muscle lactate dehydrogenase with acidic phospholipids at low pH. Biochim. Biophys. Acta 2006, 1758, 133-144. [CrossRef]

249. Crane, C.A.; Austgen, K.; Haberthur, K.; Hofmann, C.; Moyes, K.W.; Avanesyan, L.; Fong, L.; Campbell, M.J.; Cooper, S.; Oakes, S.A.; et al. Immune evasion mediated by tumor-derived lactate dehydrogenase induction of NKG2D ligands on myeloid cells in glioblastoma patients. Proc. Natl. Acad. Sci. USA 2014, 111, 12823-12828. [CrossRef]

250. Fantin, V.R.; St-Pierre, J.; Leder, P. Attenuation of LDH-A expression uncovers a link between glycolysis, mitochondrial physiology, and tumor maintenance. Cancer Cell 2006, 9, 425-434. [CrossRef] 
251. Koukourakis, M.; Tsolou, A.; Pouliliou, S.; Lamprou, I.; Papadopoulou, M.; Ilemosoglou, M.; Kostoglou, G.; Ananiadou, D.; Sivridis, E.; Giatromanolaki, A. Blocking LDHA glycolytic pathway sensitizes glioblastoma cells to radiation and temozolomide. Biochem. Biophys. Res. Commun. 2017, 491, 932-938. [CrossRef] [PubMed]

252. Vander Heiden, M.G.; Cantley, L.C.; Thompson, C.B. Understanding the Warburg effect: The metabolic requirements of cell proliferation. Science 2009, 324, 1029-1033. [CrossRef] [PubMed]

253. Gallo, M.; Sapio, L.; Spina, A.; Naviglio, D.; Calogero, A.; Naviglio, S. Lactic dehydrogenase and cancer: An overview. Front. Biosci. (Landmark Ed.) 2015, 20, 1234-1249.

254. Valvona, C.J.; Fillmore, H.L.; Nunn, P.B.; Pilkington, G.J. The Regulation and Function of Lactate Dehydrogenase A: Therapeutic Potential in Brain Tumor. Brain Pathol. 2016, 26, 3-17. [CrossRef] [PubMed]

255. Chesnelong, C.; Chaumeil, M.M.; Blough, M.D.; Al-Najjar, M.; Stechishin, O.D.; Chan, J.A.; Pieper, R.O.; Ronen, S.M.; Weiss, S.; Luchman, H.A.; et al. Lactate dehydrogenase A silencing in IDH mutant gliomas. Neuro-oncology 2014, 16, 686-695. [CrossRef]

256. Mack, N.; Mazzio, E.A.; Bauer, D.; Flores-Rozas, H.; Soliman, K.F. Stable shRNA Silencing of Lactate Dehydrogenase A (LDHA) in Human MDA-MB-231 Breast Cancer Cells Fails to Alter Lactic Acid Production, Glycolytic Activity, ATP or Survival. Anticancer Res. 2017, 37, 1205-1212.

257. Zdralevic, M.; Brand, A.; Di Ianni, L.; Dettmer, K.; Reinders, J.; Singer, K.; Peter, K.; Schnell, A.; Bruss, C.; Decking, S.M.; et al. Double genetic disruption of lactate dehydrogenases A and B is required to ablate the "Warburg effect" restricting tumor growth to oxidative metabolism. J. Biol. Chem. 2018, 293, 15947-15961. [CrossRef]

258. Wildburger, N.C.; Wood, P.L.; Gumin, J.; Lichti, C.F.; Emmett, M.R.; Lang, F.F.; Nilsson, C.L. ESI-MS/MS and MALDI-IMS Localization Reveal Alterations in Phosphatidic Acid, Diacylglycerol, and DHA in Glioma Stem Cell Xenografts. J. Proteome Res. 2015, 14, 2511-2519. [CrossRef]

259. Aragno, M.; Mastrocola, R.; Catalano, M.G.; Brignardello, E.; Danni, O.; Boccuzzi, G. Oxidative stress impairs skeletal muscle repair in diabetic rats. Diabetes 2004, 53, 1082-1088. [CrossRef]

260. Jevric-Causevic, A.; Malenica, M.; Dujic, T. Creatine kinase activity in patients with diabetes mellitus type I and type II. Bosn. J. Basic Med. Sci. 2006, 6, 5-9. [CrossRef]

261. Odum, E.P.; Young, E.E. Elevated cardiac troponin I, creatine kinase and myoglobin and their relationship with cardiovascular risk factors in patients with type 2 diabetes. Diabetes Metab. Syndr. 2018, 12, 141-145. [CrossRef]

262. Popovich, B.K.; Boheler, K.R.; Dillmann, W.H. Diabetes decreases creatine kinase enzyme activity and mRNA level in the rat heart. Am. J. Physiol. 1989, 257, E573-E577. [CrossRef]

263. Tsushima, S.; Kai, M.; Yamada, K.; Imai, S.; Houkin, K.; Kanoh, H.; Sakane, F. Diacylglycerol kinase $\gamma$ serves as an upstream suppressor of Rac1 and lamellipodium formation. J. Biol. Chem. 2004, 279, 28603-28613. [CrossRef] [PubMed]

264. Tsumagari, R.; Kakizawa, S.; Kikunaga, S.; Fujihara, Y.; Ueda, S.; Yamanoue, M.; Saito, N.; Ikawa, M.; Shirai, Y. DGK $\gamma$ Knock-Out Mice Show Impairments in Cerebellar Motor Coordination, LTD, and the Dendritic Development of Purkinje Cells through the Activation of PKC $\gamma$. eNeuro 2020, 7. [CrossRef]

265. Ferraz-Nogueira, J.P.; Diez-Guerra, F.J.; Llopis, J. Visualization of phosphatidic acid fluctuations in the plasma membrane of living cells. PLoS ONE 2014, 9, e102526. [CrossRef]

266. Potocky, M.; Pleskot, R.; Pejchar, P.; Vitale, N.; Kost, B.; Zarsky, V. Live-cell imaging of phosphatidic acid dynamics in pollen tubes visualized by Spo20p-derived biosensor. New Phytol. 2014, 203, 483-494. [CrossRef]

267. Schwarz, K.; Natarajan, S.; Kassas, N.; Vitale, N.; Schmitz, F. The synaptic ribbon is a site of phosphatidic acid generation in ribbon synapses. J. Neurosci. 2011, 31, 15996-16011. [CrossRef]

268. Yamada, H.; Hoshino, F.; Lu, Q.; Sakane, F. Cellular phosphatidic acid sensor, $\alpha$-synuclein N-terminal domain, detects endogenous phosphatidic acid in macrophagic phagosomes and neuronal growth cones. Biochem. Biophys. Rep. 2020, 22, 100769. [CrossRef]

269. Vacaru, A.M.; Tafesse, F.G.; Ternes, P.; Kondylis, V.; Hermansson, M.; Brouwers, J.F.; Somerharju, P.; Rabouille, C.; Holthuis, J.C. Sphingomyelin synthase-related protein SMSr controls ceramide homeostasis in the ER. J. Cell Biol. 2009, 185, 1013-1027. [CrossRef] [PubMed]

270. Cabukusta, B.; Kol, M.; Kneller, L.; Hilderink, A.; Bickert, A.; Mina, J.G.; Korneev, S.; Holthuis, J.C. ER residency of the ceramide phosphoethanolamine synthase SMSr relies on homotypic oligomerization mediated by its SAM domain. Sci. Rep. 2017, 7, 41290. [CrossRef] 
271. Cabukusta, B.; Köhlen, J.A.; Richter, C.P.; You, C.; Holthuis, J.C. Monitoring Changes in the Oligomeric State of a Candidate Endoplasmic Reticulum (ER) Ceramide Sensor by Single-molecule Photobleaching. J. Biol. Chem. 2016, 291, 24735-24746. [CrossRef] [PubMed]

272. Murakami, C.; Hoshino, F.; Sakai, H.; Hayashi, Y.; Yamashita, A.; Sakane, F. Diacylglycerol kinase $\delta$ and sphingomyelin synthase-related protein functionally interact via their sterile $\alpha$ motif domains. J. Biol. Chem. 2020, 295, 2932-2947. [CrossRef] [PubMed]

273. Ogushi, F.; Ishitsuka, R.; Kobayashi, T.; Sugita, Y. Rapid flip-flop motions of diacylglycerol and ceramide in phospholipid bilayers. Chem. Phys. Lett. 2012, 522, 96-102. [CrossRef]

274. Kooijman, E.E.; Burger, K.N. Biophysics and function of phosphatidic acid: A molecular perspective. Biochim. Biophys. Acta 2009, 1791, 881-888. [CrossRef] [PubMed]

275. Kamiya, Y.; Mizuno, S.; Komenoi, S.; Sakai, H.; Sakane, F. Activation of conventional and novel protein kinase $\mathrm{C}$ isozymes by different diacylglycerol molecular species. Biochem. Biophys. Rep. 2016, 7, 361-366. [CrossRef]

276. Peng, X.; Frohman, M.A. Mammalian phospholipase D physiological and pathological roles. Acta Physiol. (Oxf.) 2012, 204, 219-226. [CrossRef]

277. Bradley, R.M.; Duncan, R.E. The lysophosphatidic acid acyltransferases (acylglycerophosphate acyltransferases) family: One reaction, five enzymes, many roles. Curr. Opin. Lipidol. 2018, 29, 110-115. [CrossRef]

278. Eto, M.; Shindou, H.; Shimizu, T. A novel lysophosphatidic acid acyltransferase enzyme (LPAAT4) with a possible role for incorporating docosahexaenoic acid into brain glycerophospholipids. Biochem. Biophys. Res. Commun. 2014, 443, 718-724. [CrossRef]

279. Zhukovsky, M.A.; Filograna, A.; Luini, A.; Corda, D.; Valente, C. The Structure and Function of Acylglycerophosphate Acyltransferase 4/Lysophosphatidic Acid Acyltransferase Delta (AGPAT4/LPAAT $\delta$ ). Front. Cell Dev. Biol. 2019, 7, 147. [CrossRef]

280. De Kroon, A.I. Metabolism of phosphatidylcholine and its implications for lipid acyl chain composition in Saccharomyces cerevisiae. Biochim. Biophys. Acta 2007, 1771, 343-352. [CrossRef] [PubMed]

281. Wagner, S.; Paltauf, F. Generation of glycerophospholipid molecular species in the yeast Saccharomyces cerevisiae. Fatty acid pattern of phospholipid classes and selective acyl turnover at sn-1 and sn-2 positions. Yeast 1994, 10, 1429-1437. [CrossRef]

282. Devaiah, S.P.; Roth, M.R.; Baughman, E.; Li, M.; Tamura, P.; Jeannotte, R.; Welti, R.; Wang, X. Quantitative profiling of polar glycerolipid species from organs of wild-type Arabidopsis and a phospholipase D $\alpha 1$ knockout mutant. Phytochemistry 2006, 67, 1907-1924. [CrossRef] [PubMed]

283. Narasimhan, R.; Wang, G.; Li, M.; Roth, M.; Welti, R.; Wang, X. Differential changes in galactolipid and phospholipid species in soybean leaves and roots under nitrogen deficiency and after nodulation. Phytochemistry 2013, 96, 81-91. [CrossRef] 